\author{
A. C. Fariña · J. Freire · E. González-Gurriarán
}

\title{
Megabenthic decapod crustacean assemblages on the Galician continental shelf and upper slope (north-west Spain)
}

Received: 21 May 1996 / Accepted: 9 August 1996

\begin{abstract}
The structure of megabenthic decapod crustacean assemblages on the Galician (north-west Spain) continental shelf (100 to 200 depth) and upper slope (200 to $500 \mathrm{~m}$ ) was analyzed based on surveys carried out in autumn and spring, from 1980 to 1987 . Forty species belonging to 19 families were caught. The portunid crab Polybius henslowii, a species with pelagic phases, was the most abundant species, but displayed strong spatial and temporal fluctuations. Other dominant species were the Norway lobster Nephrops norvegicus, the portunid Liocarcinus depurator, the galatheids Munida intermedia and M. sarsi, and the shrimps Solenocera membranacea, Plesionika heterocarpus, Pasiphaea sivado and Dichelopandalus bonnieri. Total abundance and biomass (average values excluding Polybius henslowii $=255$ individuals and $2.06 \mathrm{~kg} / 30 \mathrm{~min}$ tow) and species richness and diversity, $H^{\prime}$ (6.85 species and $H^{\prime}=1.45$ per tow) displayed a significant positive correlation with depth, and strong interannual fluctuations. The factors determining community organization were depth and, to a lesser extent, spatial structure. There was clear evidence of bathymetric zonation, differentiating between species characteristic of the slope (D. bonnieri and Pasiphaea sivado), shelf-slope edge (Macropipus tuberculatus, Pontophilus spinosus, Munida sarsi, S. membranacea, Processa spp.) and shelf (L. depurator, Macropodia tenuirostris, Paguridae and Chlorotocus crassicornis). The spatial zonation was related to changes in oceanography and sediment along the continental margin. Goneplax
\end{abstract}

Communicated by A. Rodríguez, Puerto Real

A.C. Fariña

Instituto Español de Oceanografía,

Apartado 130, E-15080 A Coruña,

Spain

J. Freire $(\bowtie) \cdot$ E. González-Gurriarán

Departamento de Bioloxía Animal,

Bioloxía Vexetal e Ecoloxía,

Universidade da Coruña, Campus da Zapateira s/n,

E-15071 A Coruña,

Spain rhomboides, N. norvegicus, C. crassicornis and Alpheus glaber are benthic species which generally exhibit burrowing behaviour, and they were found mainly in the southern area where there are fine sediments due to the outwelling from the Rías Baixas. Different benthopelagic shrimps (Pontophilus spinosus, Plesionika heterocarpus, Processa spp. and Pasiphaea sivado) were typical of the zone just north of Fisterra, characterized by a convergence of water masses bringing about an increase in productivity due to upwelling. The benthic anomuran and brachyuran crabs Munida intermedia, M. sarsi, L. depurator and Macropipus tuberculatus were characteristic of the northwestern zone between Fisterra and Estaca, where the infauna reaches high biomass despite coarser sediments with a lower concentration of organic material than in the southern area. Lastly, both the Paguridae and Macropodia tenuirostris were species typically found in the waters in the northern shelf. Based on interannual changes in assemblage structure, two periods could be distinguished: between 1980 and 1984, when Polybius henslowii, D. bonnieri and Pasiphaea sivado had abundance peaks; and another period from 1985 to 1987 when L. depurator, Munida intermedia, M. sarsi and Macropipus tuberculatus increased in abundance.

\section{Introduction}

Decapod crustaceans make up one of the dominant groups of megabenthic invertebrates on the Atlantic continental shelf and slope (Lagardère 1973, 1977a; Haedrich et al. 1975, 1980; Wenner and Boesch 1979; Markle et al. 1988; Basford et al. 1989; Olaso 1990; Macpherson 1991; Bianchi 1992a,b; Setubal 1992; García-Castrillo and Olaso 1995), although the structure and organization of their communities is not as well known as that of demersal fishes (see Fariña et al. 1996). However, recent studies in the north-west Mediterranean Sea have made important data available on the 
distribution and abundance patterns of the crustacean communities, chiefly in deep waters (Abelló et al. 1988; Cartes and Sardá 1992, 1993; Cartes 1993a; Cartes et al. 1994; Sardá et al. 1994a).

The Galician continental margin (shelf and upper slope, 100 to $500 \mathrm{~m}$ depth; north-west Spain) comprises a narrow strip (30 to $60 \mathrm{~km}$ ) (see Fig. 1) characterized by seasonal upwelling (Fraga 1981; Blanton et al. 1984; McClain et al. 1986) and a high primary productivity that determines the structure of the pelagic and benthic food webs (Tenore et al. 1984; Penas 1986; López-Jamar et al. 1992; Varela 1992; Fariña et al. 1997). This area is subject to an intensive demersal fishery targeting different fish species in addition to the Norway lobster (Fernández et al. 1978; Trujillo et al. 1993; Fariña et al. 1994).

Earlier studies have been carried out on the Galician continental margin which examined the distribution patterns of some decapod species (Alonso-Allende 1980, 1982; González-Gurriarán 1987; González-Gurriarán and Olaso 1987; Freire et al. 1991, 1992; GonzálezGurriarán et al. 1993; Fariña et al. 1994; Fariña and Pereiro 1995). Only González-Gurriarán and Olaso (1987) described the structure of the decapod assemblages on the Galician continental margin, although its relationship to environmental factors and its temporal changes were not analyzed. Olaso (1990) and GarcíaCastrillo and Olaso (1995) studied the megabenthic invertebrates in the Cantabrian Sea, an area adjacent to the Galician coast. Moreover, there have been a number of studies on the structure of crustacean assemblages in the Galician rías (coastal embayments) (González-Gurriarán 1982, 1986; Romero et al. 1982; Iglesias and González-Gurriarán 1984; González-Gurriarán et al. 1991).

This paper analyzes the megabenthic crustacean assemblages on the Galician continental shelf and upper slope based on fishery research-surveys in autumn and spring between 1980 and 1987. The main purposes of the research were to examine the spatial distribution and interannual variation in the assemblages and to determine how they relate to environmental and oceanographic conditions.

\section{Materials and methods}

Sampling methodology has been described in detail in previous papers (González-Gurriarán and Olaso 1987; Sánchez et al. 1991; Fariña et al. 1994, 1997). For the present study, demersal trawl surveys carried out on the Galician continental shelf (100 to $200 \mathrm{~m}$ depth) and upper slope (200 to $500 \mathrm{~m}$ ) in autumn (1980 to 1986) and in spring (1984, 1986 and 1987) were taken into account. A "baca" type trawl gear with a $20 \mathrm{~mm}$ codend cover and an estimated opening of $22.0 \mathrm{~m}$ horizontally and $1.9 \mathrm{~m}$ vertically was used aboard the R.V. "Coornide de Saavedra". The study area was sampled according to a random stratified design. The $200 \mathrm{~m}$ isobath separated depth strata, and three geographic areas were predetermined: Miño-Fisterra (M-F), Fisterra-Estaca de Bares (F-E), and Estaca de Bares-Ribadeo (E-R) (Fig. 1). The area between 200 and $500 \mathrm{~m}$ of the E-R area was not sampled because it has a rocky bottom with a steep slope. A total of 293 tows were carried out in

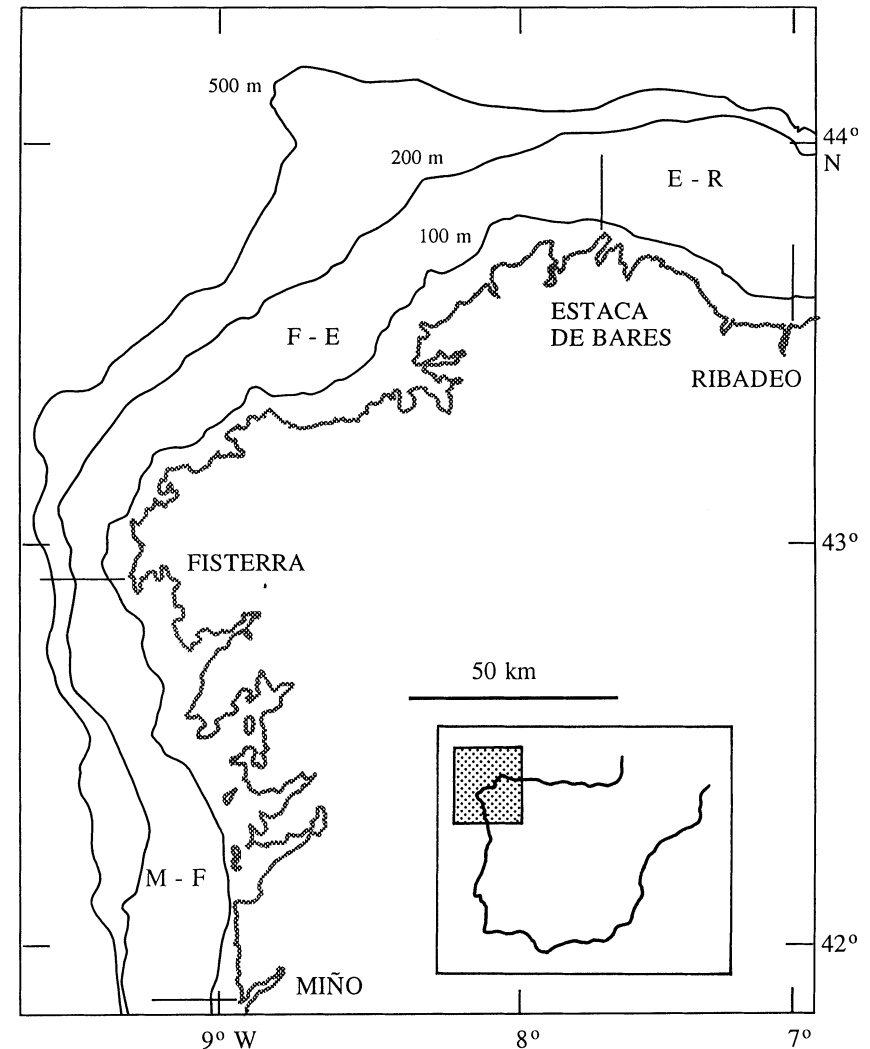

Fig. 1 Galician coast (north-west Spain). Geographic areas (M-F Miño-Fisterra; $F$ - $E$ Fisterra-Estaca de Bares; $E$ - $R$ Estaca de BaresRibadeo) and depth strata (100 to $200 \mathrm{~m}$ and 200 to $500 \mathrm{~m}$ ) sampled between 1980 and 1987

autumn and 168 in spring. Tows were carried out in daylight (08:00 to $19: 00 \mathrm{hrs}$ ) at a speed of 3 knots. Up to 1984 , each tow lasted $60 \mathrm{~min}$; in the survey of spring 1984, 60 and $30 \mathrm{~min}$ tows were carried out, and subsequently tows were $30 \mathrm{~min}$ long (data from $60 \mathrm{~min}$ tows were transformed to $30 \mathrm{~min}$, and density and biomass were defined as the number of individuals/30 min tow or gram wet $\mathrm{wt} / 30 \mathrm{~min}$ tow, respectively).

Decapod crustaceans caught in each tow were identified to species, and the number of specimens and total wet weight were recorded for each species. The different species of the family $\mathrm{Pa}-$ guridae (Pagurus prideauxi, P. alatus, P. bernhardus, P. excavatus and Anapagurus laevis) were identified on some occasions only to genus or family level, and are therefore grouped as Paguridae in this study.

Density, biomass, species richness and diversity ( $H^{\prime}$ ShannonWiener index in $\log _{2}$ ) were compared among years, seasons and geographic areas using different models of analysis of covariance (ANCOVA), where depth was included as a covariate. The portunid crab Polybius henslowii was not included in the data analyses since the catches of this species showed great spatial and temporal fluctuations (mean abundance for each survey ranged between 0 and 7808 individuals/30 min tow, with tows where as many as $\simeq 2 \times 10^{5}$ individuals were caught). This species has partially pelagic habits, occupying the entire water column and forming dense swarms (Allen 1968; González-Gurriarán 1987) that cannot be sampled adequately with the gear used.

The structure of the decapod crustacean assemblages and its relationship to different environmental factors was analyzed with different methods of correspondence analysis using the software CANOCO v. 3.12 (Ter Braak 1986, 1987) and following the methodology used with demersal fishes in the same study area (Fariña et al. 1997). Sixteen species which appeared in $\geq 5 \%$ of the tows were selected (see "Code" column in Table 1), and log- 


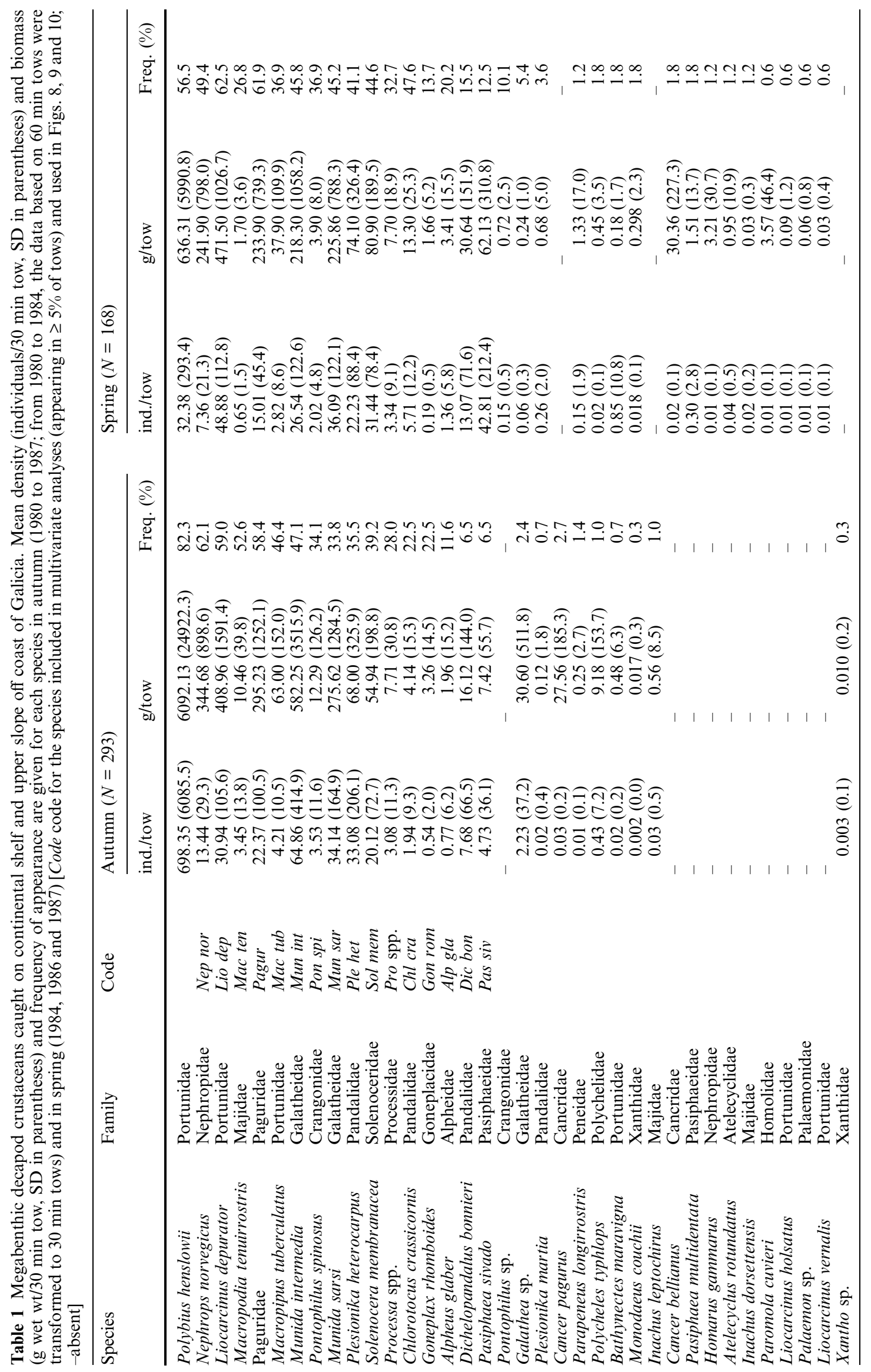


transformed density-data for each species per tow were used. The following environmental variables were included: year, season (spring and autumn as categorical variables), depth, and geographic coordinates (surface trend defined by latitude, longitude and the interaction latitude $\times$ longitude). Correspondence analysis (CA) was used to determine the patterns of variability of the assemblages; subsequently, a canonical correspondence analysis (CCA), whereby the extracted axes constituted linear combinations of the environmental variables, was carried out. Successive partial CCAs were carried out (Ter Braak 1988; Borcard et al. 1992), whereby an environmental variable was analyzed in each case, with the others being introduced as covariates.

\section{Results}

\section{Species composition}

Forty species of decapod crustaceans were caught; 31 in the seven surveys carried out in autumn and 37 during three spring surveys (Table 1). The species belonged to 19 families, the most diverse and abundant of which were Portunidae (6 species), Paguridae (5) and Pandalidae (4). Species belonging to the families Nephropidae, Galatheidae and Solenoceridae were also noteworthy in terms of density or biomass.

Polybius henslowii was the dominant species in autumn, making up $74 \%$ of the density and $73 \%$ of the biomass of the specimens caught. In spring, however, catches of this species were smaller (11.0 and 26.6\%, respectively). With the exception of $P$. henslowii, the dominant species in terms of biomass in autumn (comprising $>5 \%$ of the catches) were Munida intermedia, Liocarcinus depurator, M. sarsi, Nephrops norvegicus and Paguridae; along with Plesionika heterocarpus and Solenocera membranacea these represented $>5 \%$ of the catches in number. In autumn, these species combined made up $87 \%$ of the density and $91 \%$ of the biomass, excluding Polybius henslowii. In spring, each of the above-mentioned species constituted $>5 \%$ of density (except $N$. norvegicus) and biomass (except Plesionika heterocarpus and S. membranacea). Dichelopandalus bonnieri and Pasiphaea sivado also made up $>5 \%$ of the catches in number of individuals. The dominant species in spring corresponded to a total of $93 \%$ in density and $92 \%$ in biomass.

\section{Abundance and biomass}

The density and biomass of the decapods increased significantly as a function of increasing depth (Figs. 2 and 3 ); depth was the most important factor explaining the variability in the catches, particularly in spring (in terms of percentage of explained variance in ANCOVA, Table 2). Total density and biomass (excluding Polybius henslowii) were very similar in the autumn (mean $\pm \mathrm{SD}$ : $251 \pm 573$ individuals and $2.23 \pm 4.98 \mathrm{~kg} / 30 \mathrm{~min}$ tow $)$ and spring $(261 \pm 401$ individuals and $1.75 \pm 2.41 \mathrm{~kg} /$ tow) surveys (Fig. 3, Table 3, $P>0.1$ ). Geographic
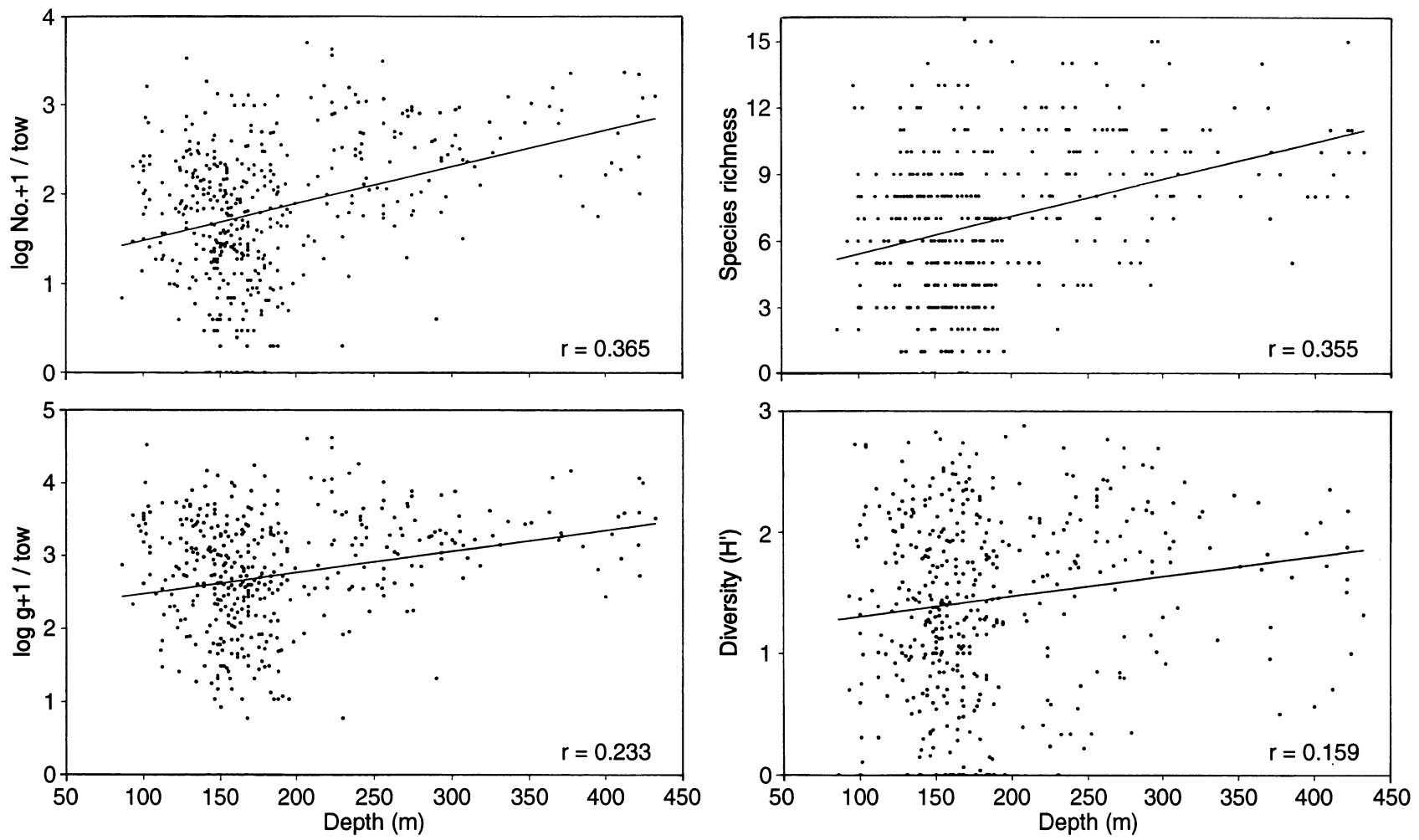

Fig. 2 Density (individuals/30 min tow), biomass ( $\mathrm{kg}$ wet $\mathrm{wt} / 30 \mathrm{~min}$ tow), species richness and diversity ( $H^{\prime}$ index) of decapod crustaceans of the Galician coast as a function of mean depth of each tow. Correlation coefficient $(r, P<0.001)$ and linear regression is shown in all cases 
Fig. 3 Density (individuals/ 30 min tow) and biomass ( $\mathrm{kg}$ wet wt/30 min tow) of decapod crustaceans as a function of geographic area and depth strata. Mean values \pm SE are shown for autumn and spring surveys (Abbreviations as in Fig. 1)
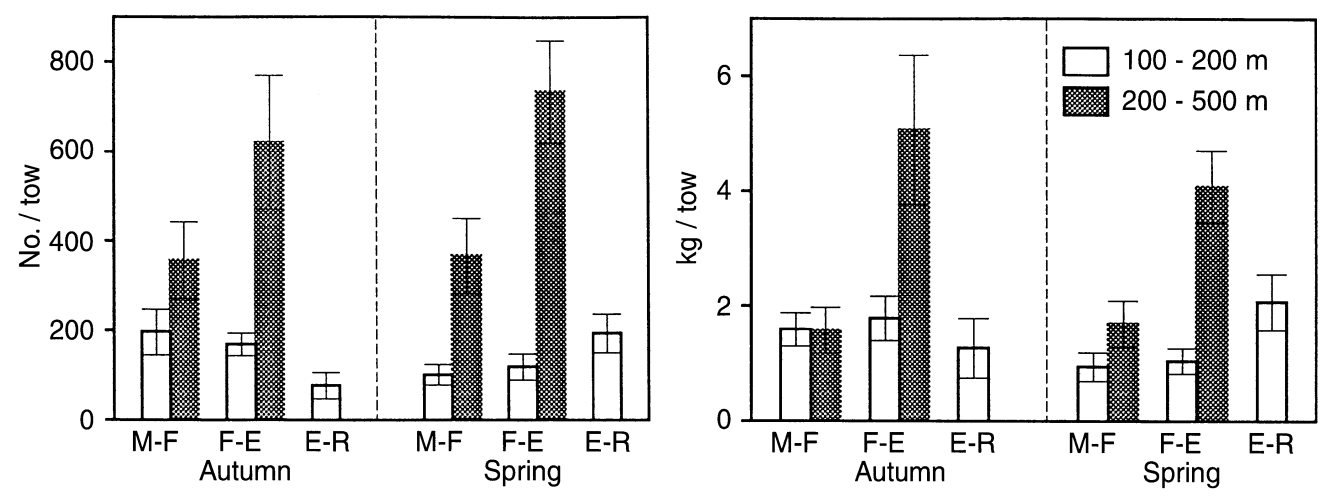

variability was of little importance in the catches. Biomass in F-E was higher than in M-F (more than twice as much at $>200 \mathrm{~m}$ depth), even though the differences only reached significant values in autumn, due to the inclusion of the 1980 and 1981 surveys $(P<0.05)$. Density followed the same pattern, especially in the slope area, although no significant differences were found between areas.

Interannual fluctuations in decapod density and biomass were marked (Fig. 4, Table 2, $P<0.001$ in all analyses), and constituted the most important factor in the autumn surveys, whereas in spring, depth accounted for a greater percentage of variance. Between 1980 and 1983 , when the surveys were made only in autumn, catches were low (with minimum values for the 100 to $200 \mathrm{~m}$ stratum of 27 individuals and $0.58 \mathrm{~kg} /$ tow in 1980 in $\mathrm{M}-\mathrm{F}$ and 18 individuals and $0.26 \mathrm{~kg} / \mathrm{tow}$ in 1983 in F-E). In subsequent years catches increased; however, the trend varied depending on geographic area and depth (significant interaction, $P<0.05$ ). In Area M-F, maximum density was attained in the autumn of 1984 (684 individuals/tow at $>200 \mathrm{~m}$ ) and maximum biomass in the autumn of $1986(3.52 \mathrm{~kg} /$ tow). In the F-E area, maximum values were attained at $>200 \mathrm{~m}$ in the autumn of 1986 (1470 individuals and $12.3 \mathrm{~kg} /$ tow $)$. In the northern area, E-R, catches reached 387 individuals and $4.26 \mathrm{~kg} /$ tow in the spring survey of 1987.

\section{Species richness and diversity}

The mean number of species caught per tow was $6.9 \pm 3.3$ and diversity $\left(H^{\prime}\right.$ index $)$ was $1.45 \pm 0.73$, with maximum values of 16 and 2.98, respectively. Species richness and diversity increased with increasing depth (Fig. 2) and no significant differences were detected between the autumn and spring surveys (Fig. 5, Table 3; $P>0.1)$. Geographic differences in both parameters were of minor quantitative importance and were largely due to increases in the F-E area.

Interannual differences in species richness and diversity in the autumn surveys were mainly due to the low values recorded in 1980 (mean values of tows carried out at $<200 \mathrm{~m}: 1.9$ species/tow and $H^{\prime}=0.28$ in Area M-F and 3.0 species/tow and $H^{\prime}=0.46$ in Area F-E) (Fig. 6, Table 2, $P<0.001$ for the 1980 to 1986 series, $P>0.1$ for the 1982 to 1986 series). There were significant differences among the different spring surveys; however, these depended on geographic area and depth stratum. Maximum values were consistently obtained in the F-E area in the autumn cruises $(<200 \mathrm{~m}: 9.3$ species/tow in 1986 and $H^{\prime}=1.83$ in $1985 ;>200 \mathrm{~m}: 11.9$ species/tow in 1986 and $H^{\prime}=2.10$ in 1981).

Spatial and temporal changes of the dominant species

The density of the dominant crustacean species underwent major spatial and temporal changes on the Galician coast (Fig. 7). Polybius henslowii appeared almost exclusively from Miño to Estaca, with very high densities throughout the entire depth range in the 1980 to 1983 period, and particularly in 1980 and 1981. Most species had wide bathymetric ranges, although the $\mathrm{Pa}$ guridae appeared almost exclusively at $<200 \mathrm{~m}$, Macropipus tuberculatus, Munida intermedia, M. sarsi and Solenocera membranacea were more abundant on the upper slope, and Dichelopandalus bonnieri and Pasiphaea sivado were only caught on the slope. In the northern zone, Area E-R, catches of Nephrops norvegicus, M. intermedia, M. sarsi, Plesionika heterocarpus and S. membranacea were rare. (D. bonnieri and Pasiphaea sivado were not caught in this area as tows were not carried out on the slope.) Liocarcinus depurator, $M$. intermedia, $M$. sarsi and $P$. sivado were present in greater abundance in Area F-E, whereas Plesionika heterocarpus and D. bonnieri were more abundant in the south, in Area M-F.

The only important seasonal differences detected were in the abundance of Macropipus tuberculatus, Munida intermedia and $M$. sarsi, whose densities were greater in autumn than in spring. In contrast, however, major interannual differences in density affected several species. One group of species increased in density over the years under study (Liocarcinus depurator, Macropipus tuberculatus between Miño and Estaca, and Munida intermedia and M. sarsi between Fisterra and Estaca). Another group which underwent strong fluctuations but displayed no clear trend was made up of Paguridae, 
Table 2 Results of analyses of covariance comparing density $\left(\log _{10}\right.$ individuals $/ 30 \mathrm{~min}$ tow), biomass ( $\log _{10} \mathrm{~g}$ wet wt/30 min tow), species richness and diversity (index $H^{\prime}$ ) of decapod crustaceans between years and geographic areas, with depth as covariate $(\%$ expl percent explained variance; area abbreviations as in Fig. 1)

\begin{tabular}{|c|c|c|c|c|c|c|c|c|c|}
\hline \multirow[t]{2}{*}{$\begin{array}{l}\text { Source of } \\
\text { variation }\end{array}$} & \multicolumn{3}{|c|}{$\begin{array}{l}\text { Cruises G80-G86 } \\
\text { (Areas M-F, F-E) }\end{array}$} & \multicolumn{3}{|c|}{$\begin{array}{l}\text { Cruises G82-G86 } \\
\text { (Areas M-F, F-E, E-R) }\end{array}$} & \multicolumn{3}{|c|}{$\begin{array}{l}\text { Cruises W84, W86, W87 } \\
\text { (Areas M-F, F-E, E-R) }\end{array}$} \\
\hline & $(d f)$ & $F(P)$ & $\%$ expl & $(d f)$ & $F(P)$ & $\%$ expl & $(d f)$ & $F(P)$ & $\%$ expl \\
\hline $\begin{array}{l}\text { Density } \\
\text { depth } \\
\text { year } \\
\text { area } \\
\text { year } \times \text { area } \\
\text { error }\end{array}$ & $\begin{array}{r}(1) \\
(6) \\
(1) \\
(6) \\
(244)\end{array}$ & $\begin{array}{r}11.13(0.001) \\
11.02(0.000) \\
1.06(0.304) \\
3.12(0.006)\end{array}$ & $\begin{array}{r}4.6 \\
27.1 \\
0.4 \\
7.7\end{array}$ & $\begin{array}{r}(1) \\
(4) \\
(2) \\
(8) \\
(229)\end{array}$ & $\begin{array}{r}17.02(0.000) \\
5.93(0.000) \\
1.18(0.308) \\
3.64(0.001)\end{array}$ & $\begin{array}{r}7.4 \\
10.4 \\
1.0 \\
12.7\end{array}$ & $\begin{array}{r}(1) \\
(2) \\
(2) \\
(4) \\
(157)\end{array}$ & $\begin{array}{r}58.11(0.000) \\
9.95(0.000) \\
1.73(0.181) \\
9.61(0.000)\end{array}$ & $\begin{array}{r}37.0 \\
6.3 \\
1.1 \\
6.1\end{array}$ \\
\hline $\begin{array}{l}\text { Biomass } \\
\text { depth } \\
\text { year } \\
\text { area } \\
\text { year } \times \text { area } \\
\text { error }\end{array}$ & $\begin{array}{r}(1) \\
(6) \\
(1) \\
(6) \\
(244)\end{array}$ & $\begin{array}{l}1.55(0.215) \\
7.26(0.000) \\
4.81(0.029) \\
2.93(0.006)\end{array}$ & $\begin{array}{r}0.6 \\
29.5 \\
3.3 \\
11.9\end{array}$ & $\begin{array}{r}(1) \\
(4) \\
(2) \\
(8) \\
(229)\end{array}$ & $\begin{array}{l}4.78(0.030) \\
4.42(0.002) \\
1.56(0.213) \\
3.36(0.001)\end{array}$ & $\begin{array}{r}2.1 \\
7.7 \\
1.4 \\
11.7\end{array}$ & $\begin{array}{r}(1) \\
(2) \\
(2) \\
(4) \\
(157)\end{array}$ & $\begin{array}{r}22.37(0.000) \\
18.90(0.000) \\
2.53(0.083) \\
6.13(0.000)\end{array}$ & $\begin{array}{r}14.3 \\
3.6 \\
3.2 \\
15.6\end{array}$ \\
\hline $\begin{array}{l}\text { Species richness } \\
\text { depth } \\
\text { year } \\
\text { area } \\
\text { year } \times \text { area } \\
\text { error }\end{array}$ & $\begin{array}{r}(1) \\
(6) \\
(1) \\
(6) \\
(244)\end{array}$ & $\begin{array}{r}19.40(0.000) \\
13.08(0.000) \\
4.86(0.028) \\
2.87(0.010)\end{array}$ & $\begin{array}{r}8.0 \\
35.8 \\
2.2 \\
7.9\end{array}$ & $\begin{array}{r}(1) \\
(4) \\
(2) \\
(8) \\
(229)\end{array}$ & $\begin{array}{r}20.20(0.000) \\
1.95(0.103) \\
9.18(0.000) \\
4.12(0.000)\end{array}$ & $\begin{array}{r}8.8 \\
3.4 \\
8.0 \\
14.4\end{array}$ & $\begin{array}{r}(1) \\
(2) \\
(2) \\
(4) \\
(157)\end{array}$ & $\begin{array}{r}19.29(0.000) \\
3.99(0.020) \\
1.00(0.370) \\
2.93(0.023)\end{array}$ & $\begin{array}{r}12.3 \\
5.1 \\
1.3 \\
7.5\end{array}$ \\
\hline $\begin{array}{l}\text { Diversity }\left(\mathrm{H}^{\prime}\right) \\
\text { depth } \\
\text { year } \\
\text { area } \\
\text { year } \times \text { area } \\
\text { error }\end{array}$ & $\begin{array}{r}(1) \\
(6) \\
(1) \\
(6) \\
(235)\end{array}$ & $\begin{array}{l}3.12(0.079) \\
5.93(0.000) \\
2.11(0.148) \\
0.38(0.892)\end{array}$ & $\begin{array}{r}1.3 \\
15.1 \\
0.9 \\
1.0\end{array}$ & $\begin{array}{r}(1) \\
(4) \\
(2) \\
(8) \\
(223)\end{array}$ & $\begin{array}{l}2.85(0.093) \\
1.03(0.395) \\
1.31(0.273) \\
1.01(0.427)\end{array}$ & $\begin{array}{l}1.3 \\
1.8 \\
1.2 \\
3.6\end{array}$ & $\begin{array}{r}(1) \\
(2) \\
(2) \\
(4) \\
(155)\end{array}$ & $\begin{array}{l}0.35(0.554) \\
3.50(0.033) \\
2.81(0.063) \\
1.42(0.231)\end{array}$ & $\begin{array}{l}0.2 \\
4.2 \\
3.4 \\
3.4\end{array}$ \\
\hline
\end{tabular}

Table 3 Results of analyses of covariance comparing density $\left(\log _{10}\right.$ individuals $/ 30 \mathrm{~min}$ tow), biomass $\left(\log _{10} \mathrm{~g}\right.$ wet $\mathrm{wt} / 30 \mathrm{~min}$ tow). species richness and diversity (index $H^{\prime}$ ) of decapod crustaceans between seasons and geographic areas, with depth as covariate (\% expl percent explained variance; area abbreviations as in Fig. 1)

\begin{tabular}{|c|c|c|c|}
\hline \multirow[t]{2}{*}{$\begin{array}{l}\text { Source of } \\
\text { variation }\end{array}$} & \multicolumn{3}{|c|}{$\begin{array}{l}\text { Areas M-F, F-E, E-R } \\
\text { (seasons autumn / spring) }\end{array}$} \\
\hline & $(d f)$ & $F(P)$ & $\% \operatorname{expl}$ \\
\hline $\begin{array}{l}\text { Density } \\
\text { depth } \\
\text { area } \\
\text { season } \\
\text { area } \times \text { season } \\
\text { error }\end{array}$ & $\begin{array}{l}(1) \\
(2) \\
(1) \\
(2) \\
(453)\end{array}$ & $\begin{array}{r}54.64(0.000) \\
4.58(0.033) \\
0.95(0.389) \\
1.05(0.352)\end{array}$ & $\begin{array}{r}12.1 \\
1.0 \\
0.4 \\
0.5\end{array}$ \\
\hline $\begin{array}{l}\text { Biomass } \\
\text { depth } \\
\text { area } \\
\text { season } \\
\text { area } \times \text { season } \\
\text { error }\end{array}$ & $\begin{array}{l}(1) \\
(2) \\
(1) \\
(2) \\
(453)\end{array}$ & $\begin{array}{r}17.12(0.000) \\
2.65(0.072) \\
1.08(0.299) \\
0.66(0.519)\end{array}$ & $\begin{array}{l}3.8 \\
1.2 \\
0.2 \\
0.3\end{array}$ \\
\hline $\begin{array}{l}\text { Species richness } \\
\text { depth } \\
\text { area } \\
\text { season } \\
\text { area } \times \text { season } \\
\text { error }\end{array}$ & $\begin{array}{l}(1) \\
(2) \\
(1) \\
(2) \\
(453)\end{array}$ & $\begin{array}{r}47.06(0.000) \\
7.25(0.001) \\
1.67(0.197) \\
0.73(0.482)\end{array}$ & $\begin{array}{r}10.4 \\
3.2 \\
0.4 \\
0.3\end{array}$ \\
\hline $\begin{array}{l}\text { Diversity }\left(\mathrm{H}^{\prime}\right) \\
\text { depth } \\
\text { area } \\
\text { season } \\
\text { area } \times \text { season } \\
\text { error }\end{array}$ & $\begin{array}{l}(1) \\
(2) \\
(1) \\
(2) \\
(439)\end{array}$ & $\begin{array}{l}6.83(0.009) \\
3.54(0.030) \\
0.04(0.847) \\
0.92(0.400)\end{array}$ & $\begin{array}{l}1.6 \\
1.6 \\
0.0 \\
0.4\end{array}$ \\
\hline
\end{tabular}

Plesionika heterocarpus, Dichelopnadalus bonnieri and Pasiphaea sivado. Polybius henslowii was the only species that displayed a negative density trend.

Assemblage structure and faunal zonations

Indirect gradient analysis (CA) indicated that depth was the factor determining the assemblage structure (Table 4 , Fig. 8), showing a high correlation with the first axis extracted $(r=+0.51, P<0.001)$. Although the second axis also correlated with depth $(r=-0.22, P<0.001)$, for the most part it reflected geographic changes, differentiating Area E-R tows from tows in the other areas. We observed high interannual variability within each geographic area and depth stratum, although no clear trend could be determined. There were no major seasonal differences, as indicated by the fact that the centroids of the autumn and spring surveys corresponding to the same years are located close together on the plane formed by Axes 1 and 2 (Fig. 8b). The results of the direct gradient analysis (CCA) were similar, with Axis 1 (which represents $41 \%$ of the species-environment correlation) being linked to depth, while the interannual changes, correlated mostly with Axis 2, were more important than the geographic ones which were associated with Axis 3 (32\% compared to $15 \%$ of the species-environment correlation). 
Fig. 4 Time-series of density (individuals/30 min tow) and biomass (kg wet wt/ 30 min tow) of decapod crustaceans for each geographic area and depth strata. Mean values \pm SE are shown for autumn and spring surveys in each year
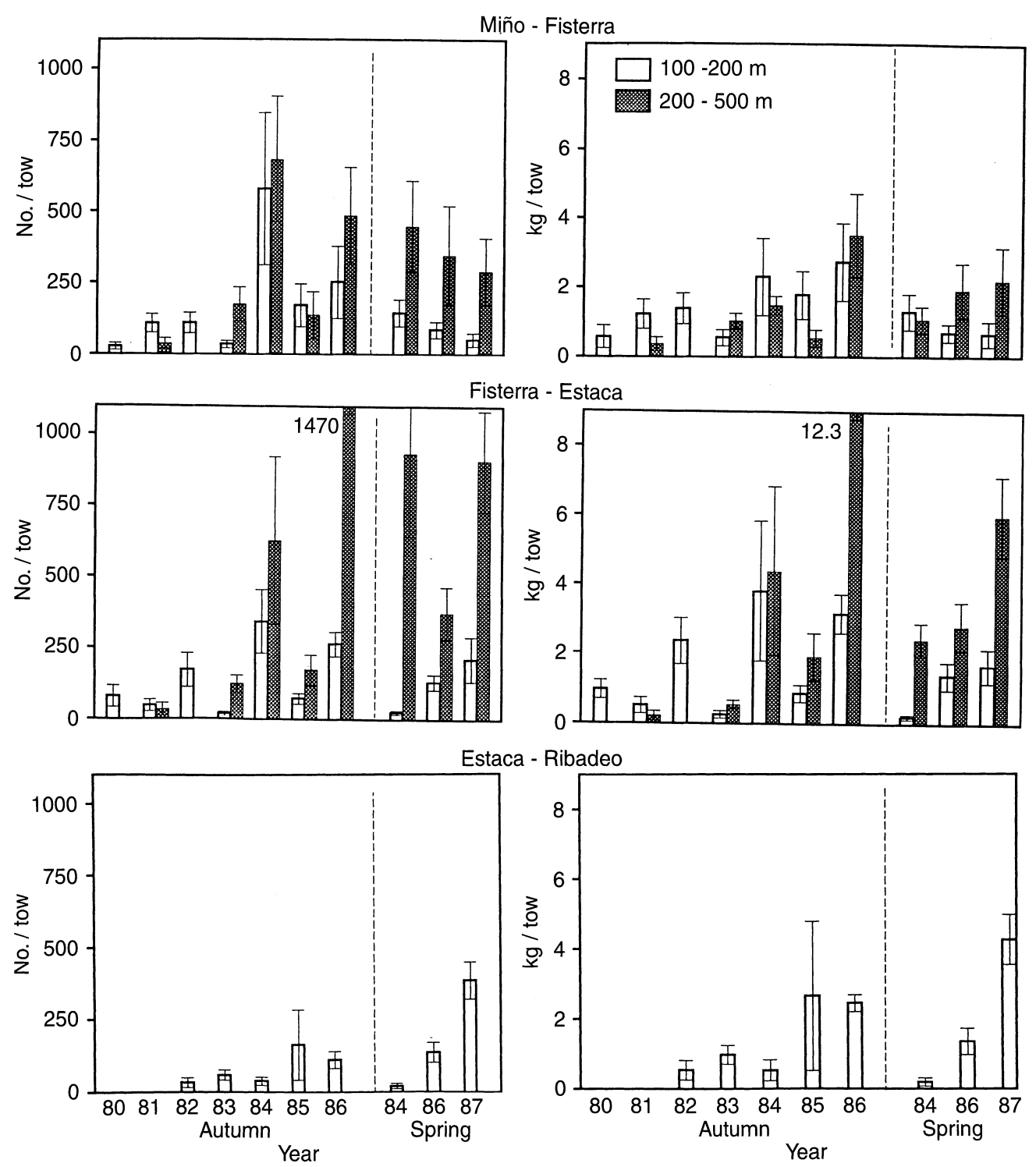

Partial CCAs were used to obtain the ordination of the species along the gradients defined by a sole environmental variable, previously eliminating the effect of other variables (Table 4, Fig. 9). All factors tested had a significant effect on assemblage structure (Monte-Carlo randomization tests with 99 permutations, $P=0.01$ ).
However, the magnitude of the canonical eigenvalues indicate that the importance of depth, year and geographic location was similar and greater than the effect of season. All species had wide temporal ranges, but the outstanding periods were from 1980 to 1984 (associated with Macropodia tenuirostris, Pontophilus spinosus, Di-
Fig. 5 Species richness and diversity $\left(H^{\prime}\right)$ of decapod crustaceans as a function of geographic area and depth strata. Mean values per tow \pm SE are shown for autumn and spring surveys (Abbreviations as in Fig. 1)
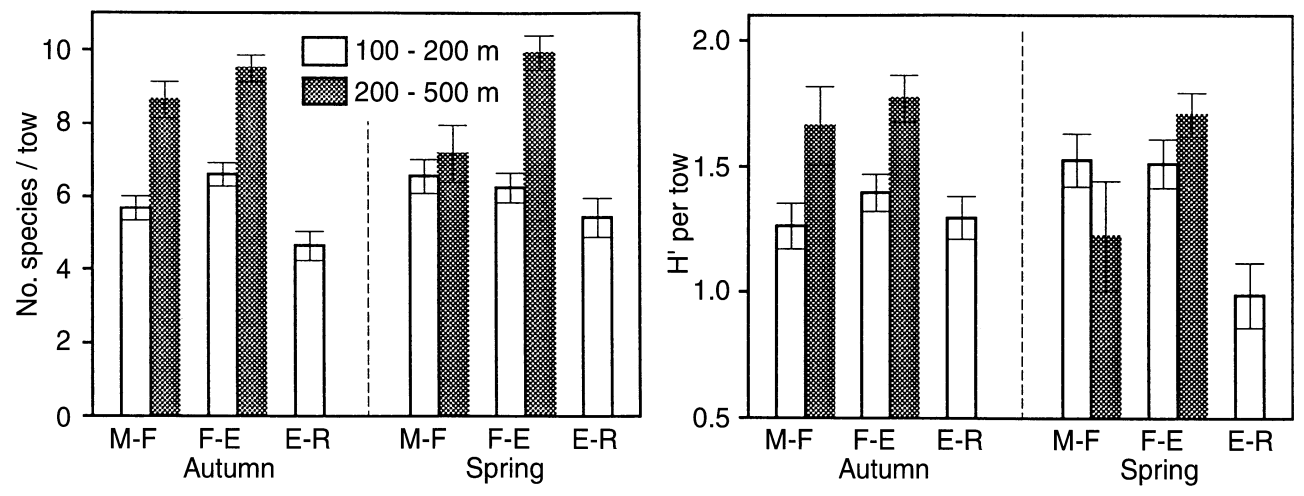
Fig. 6 Time-series of species richness and diversity $\left(H^{\prime}\right)$ of decapod crustaceans as a function of geographic area and depth strata. Mean values per tow $\pm \mathrm{SE}$ are shown for autumn and spring surveys in each year
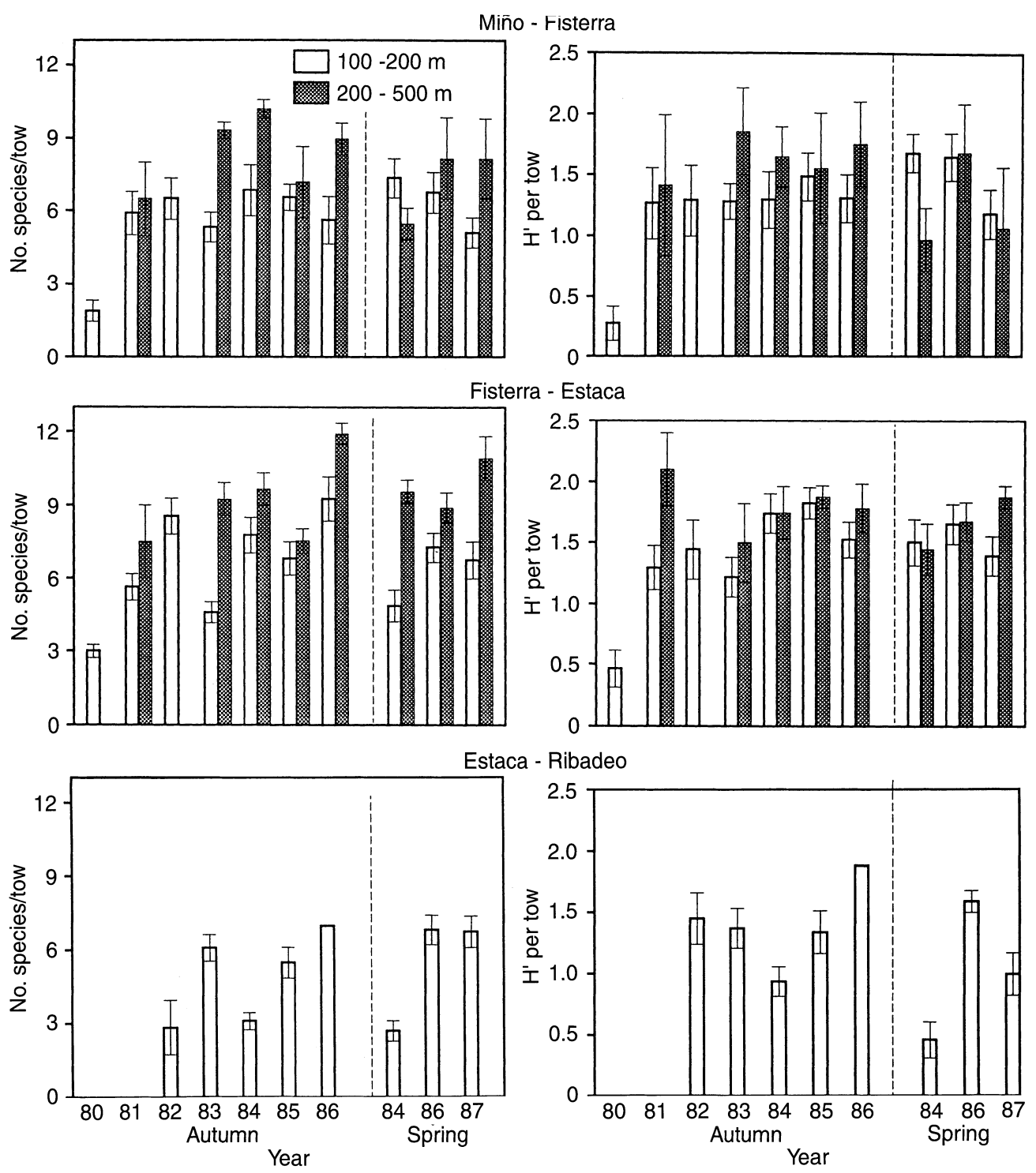

chelopandalus bonnieri and Pasiphaea sivado) and from 1985 to 1987 (associated with Liocarcinus depurator, Macropipus tuberculatus, Munida intermedia, M. sarsi and Gonoplax rhomboides). Seasonal differences were not important and did not affect the dominant species (Chlorotocus crassicornis, D. bonnieri, and Pasiphaea sivado were more abundant in spring, while Macropodia tenuirostris, Macropipus tuberculatus and G. rhomboides were more abundant in autumn).

The ordination along the bathymetric gradient (Fig. 9) revealed a clear faunal zonation between species typical of the slope (Dichelopandalus bonnieri and Pasiphaea sivado), outer shelf and upper slope (Macropipus tuberculatus, Pontophilus spinosus, Munida sarsi, Solenocera membranacea and Processa spp.) and of the shelf (Liocarcinus depurator, Macropodia tenuirostris, Paguridae and Chlorotocus crassicornis). A major geographic zonation is also evident (Fig. 10), with four large areas: the southern zone (associated with Nephrops norvegicus,
C. crassicornis, Goneplax rhomboides and Alpheus glaber); the zone to the north of Fisterra, where shrimps reached their greatest abundance with narrow distribution ranges (Pontophilus spinosus, Plesionika heterocarpus, Solenocera membranacea, Processa spp. and Pasiphaea sivado); the central zone of Area F-E (where the anomuran and brachyuran crabs were mainly found: Macropipus tuberculatus, L. depurator, Munida intermedia and M. sarsi); and Area E-R (Macropodia tenuirostris and Paguridae were species characteristic of this area, but displayed a broad geographic distribution).

\section{Discussion}

The structure of decapod crustacean assemblages on the continental margins in different geographic areas is 
Miño-Fisterra
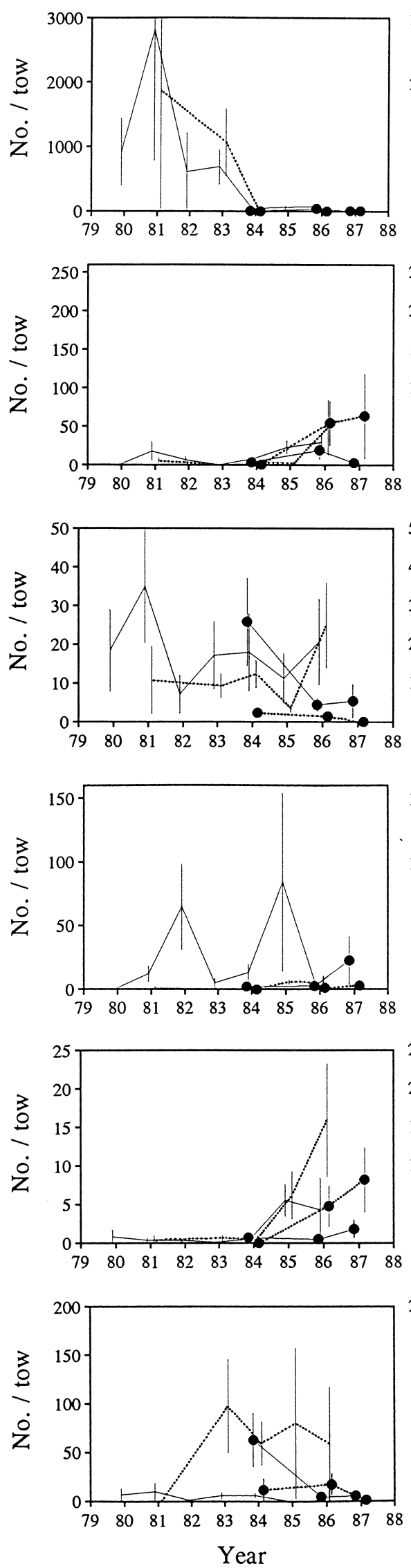

Fisterra-Estaca
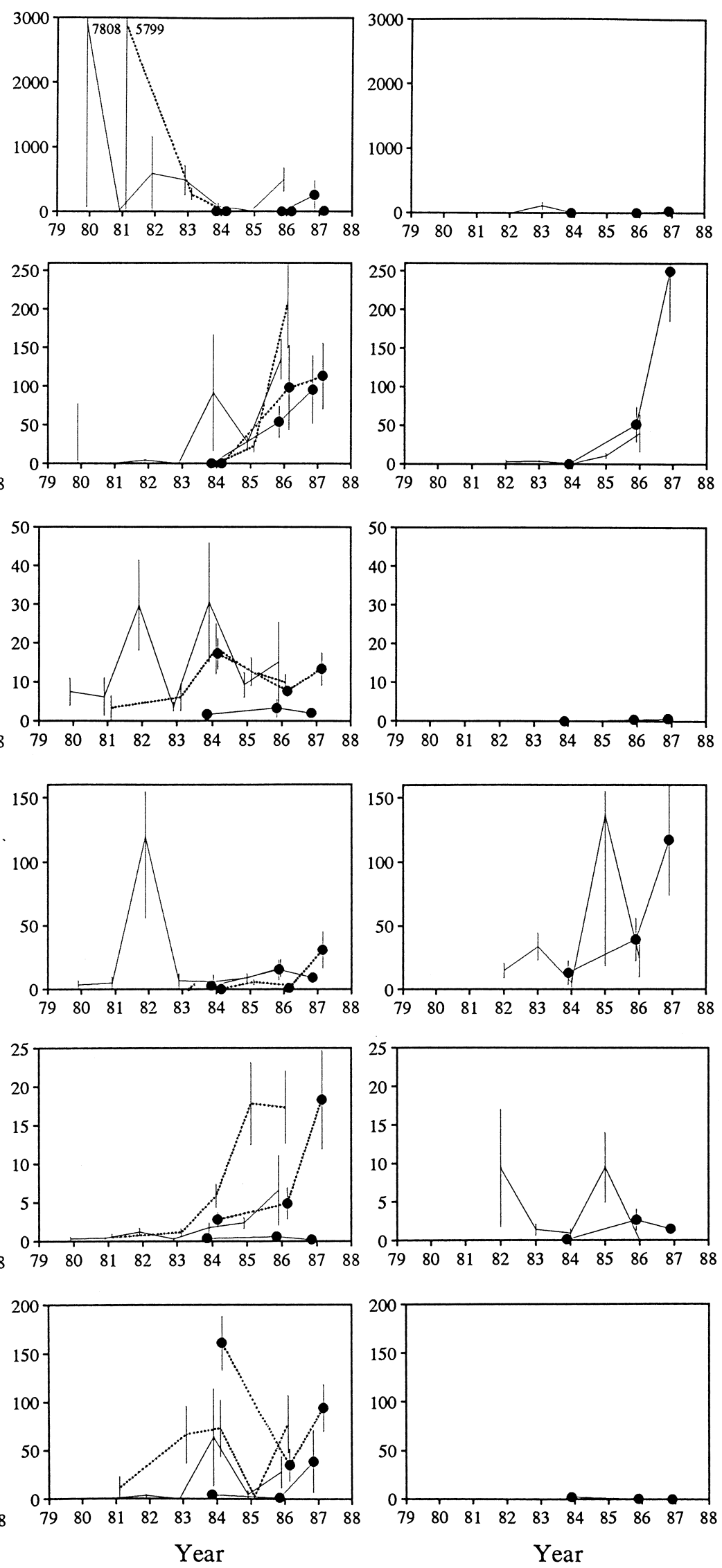

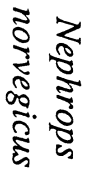

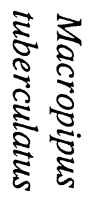

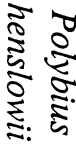

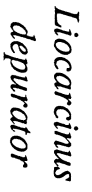

.

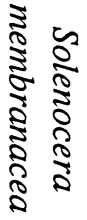

(continued overleaf) 

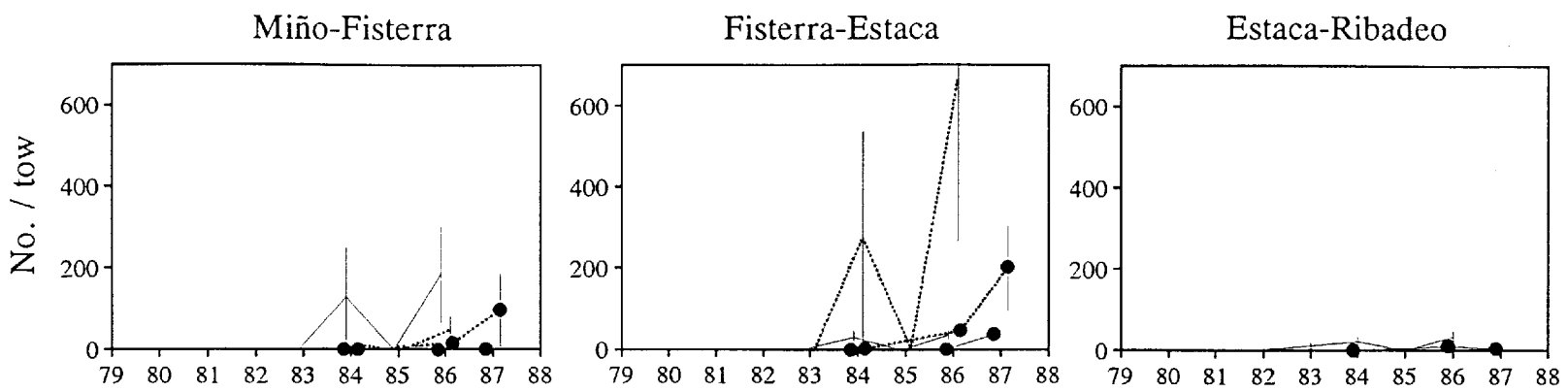

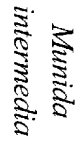
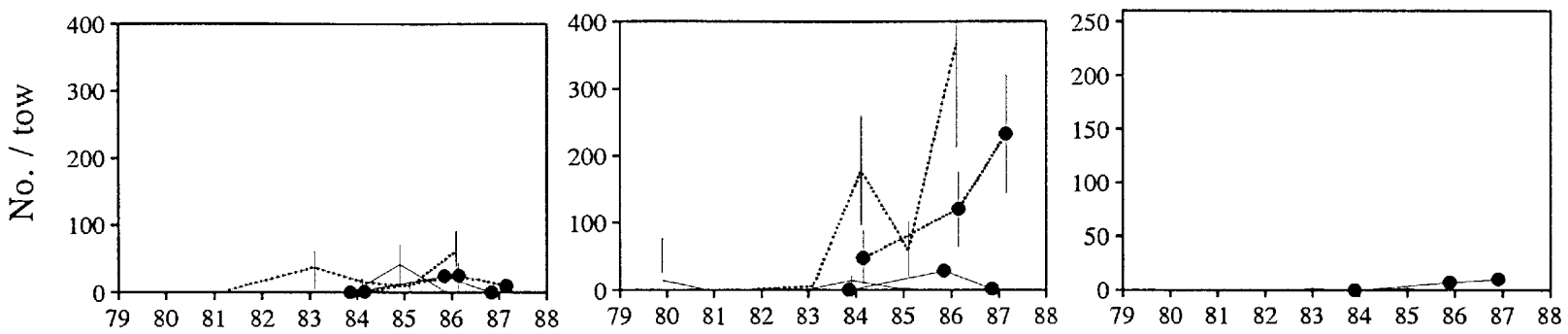

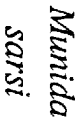
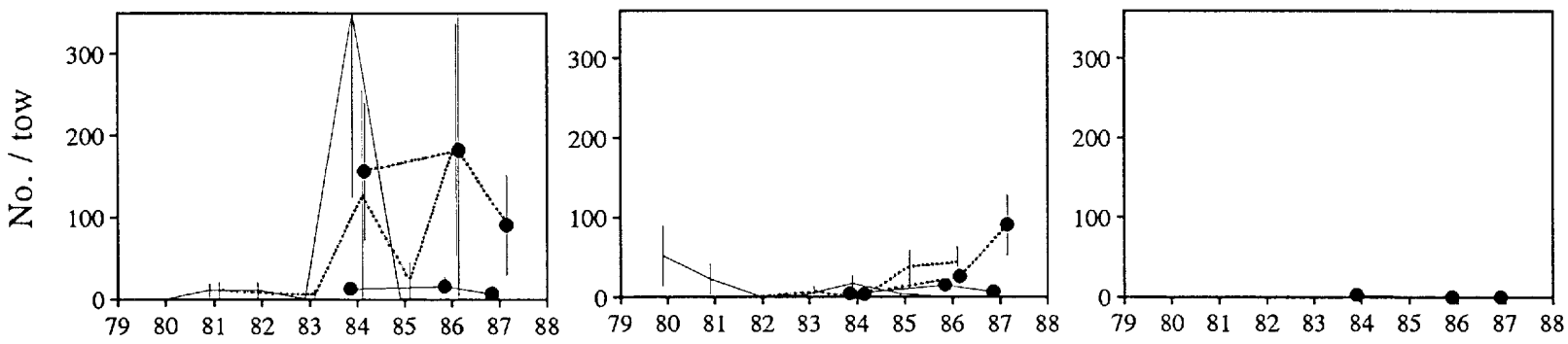

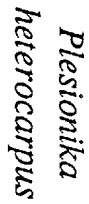
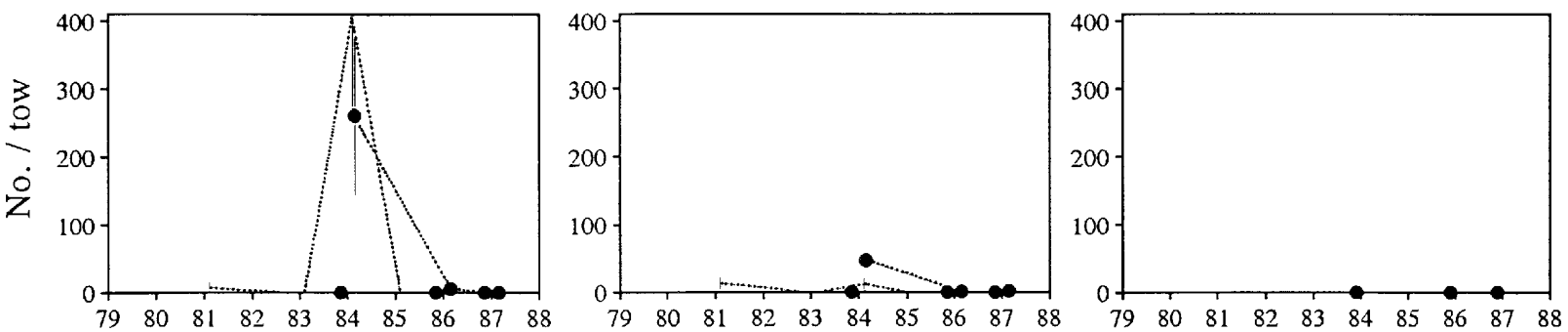

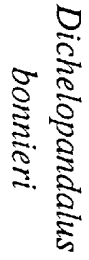
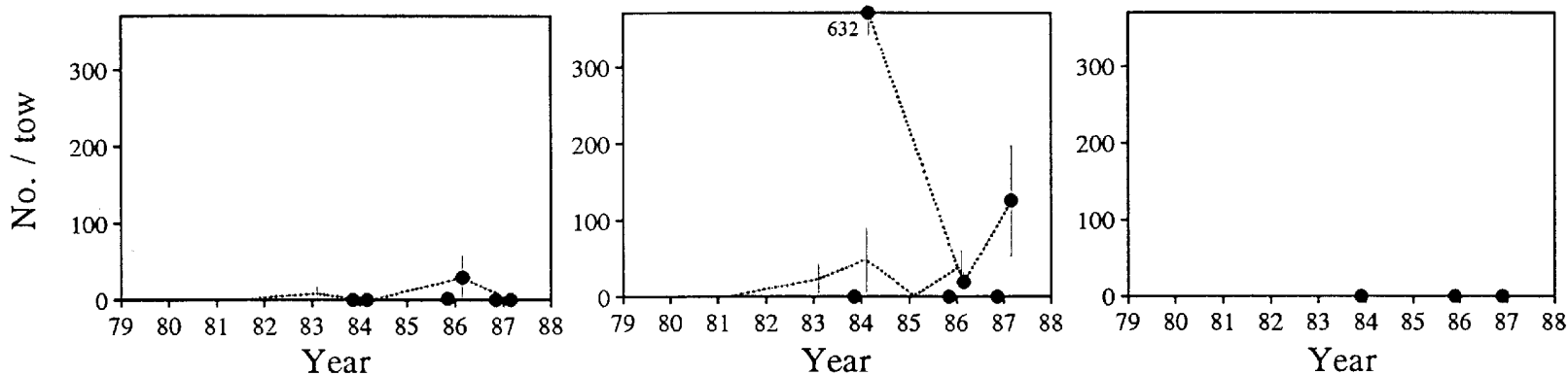

के

Fig. 7 Time-series of density (individuals/30 min tow) of dominant species of decapod crustaceans in each geographic area and depth strata (continuous lines joining data points 100 to $200 \mathrm{~m}$; dotted lines joining data points 200 to $500 \mathrm{~m}$ ). Mean values \pm SE are shown for surveys carried out in autumn (lines joining vertical bars 1980 to 1986) and in spring (lines joining data points 1984, 1986 and 1987)

largely determined by spatial differences in environmental and oceanographic conditions, and in particular, by depth, bottom type and characteristics of the water masses (Lagardère 1973, 1977a; Haedrich et al. 1975, 1980; Wenner and Boesch 1979; González-Gurriarán and Olaso 1987; Abelló et al. 1988; Markle et al. 1988;
Basford et al. 1989; Olaso 1990; Macpherson 1991; Bianchi 1992a,b; Setubal 1992; Cartes 1993a; Cartes and Sardá 1993; Cartes et al. 1994; Sardá et al. 1994a; García-Castrillo and Olaso 1995).

Off the Galician coast, there is a marked faunal zonation along the bathymetric gradient that is especially 
Table 4 Results of correspondence analyses $(C A)$ analyzing structure of decapod crustacean assemblage. Data are eigenvalues of first four axes extracted with (in parentheses) percentage of variance explained of the species data [E total sum of all eigenvalues; $E c$ sum of all canonical eigenvalues (in both cases after fitting covariates)]; correlation species-environment, $r$ (in parentheses percentage of variance explained of relationship species-environment); and correlation between the different environmental variables and each axis (for canonical CA) [ $Y$ year; $S$ season (autumn/spring); $D$ depth; $G$ geographical location (latitude, longitude, latitude $\times$ longitude)]

\begin{tabular}{|c|c|c|c|c|c|c|c|}
\hline \multirow{2}{*}{$\begin{array}{l}\text { Analysis } \\
\text { environmental variables }\end{array}$} & \multirow[t]{2}{*}{ Covariates } & \multicolumn{4}{|l|}{ Axis: } & \multirow[t]{2}{*}{ E total } & \multirow[t]{2}{*}{ Ec } \\
\hline & & 1 & 2 & 3 & 4 & & \\
\hline \multicolumn{8}{|l|}{ Non-canonical CA } \\
\hline- & - & $\begin{array}{l}0.376 \\
(13.9)\end{array}$ & $\begin{array}{l}0.347 \\
(12.8)\end{array}$ & $\begin{array}{l}0.260 \\
(9.4)\end{array}$ & $\begin{array}{l}0.206 \\
(7.7)\end{array}$ & 2.705 & - \\
\hline \multicolumn{8}{|l|}{ Canonical CA } \\
\hline $\mathrm{Y}, \mathrm{S}, \mathrm{D}, \mathrm{G}$ & - & $\begin{array}{l}0.224 \\
(8.1)\end{array}$ & $\begin{array}{l}0.175 \\
(6.3)\end{array}$ & $\begin{array}{l}0.080 \\
(2.9)\end{array}$ & $\begin{array}{l}0.038 \\
(1.3)\end{array}$ & 2.705 & 0.549 \\
\hline$r$ & & $\begin{array}{l}0.813 \\
(40.8)\end{array}$ & $\begin{array}{l}0.734 \\
(31.9)\end{array}$ & $\begin{array}{l}0.572 \\
(14.5)\end{array}$ & $\begin{array}{l}0.462 \\
(7.0)\end{array}$ & & \\
\hline \multicolumn{8}{|c|}{$\begin{array}{l}\text { Correlation axis-environmental variable } \\
\text { year }\end{array}$} \\
\hline season (autumn) & & -0.280 & -0.948 & -0.064 & -0.114 & & \\
\hline depth & & -0.056 & -0.553 & 0.496 & -0.649 & & \\
\hline latitude & & 0.834 & -0.454 & 0.287 & -0.105 & & \\
\hline longitude & & 0.074 & -0.328 & 0.671 & 0.160 & & \\
\hline latitude $\times$ longitude & & 0.289 & 0.139 & -0.676 & -0.565 & & \\
\hline & & 0.351 & 0.076 & -0.608 & -0.611 & & \\
\hline \multicolumn{8}{|l|}{ Partial canonical CA } \\
\hline $\mathrm{Y}$ & $\mathrm{S}, \mathrm{D}, \mathrm{G}$ & $\begin{array}{l}0.144 \\
(6.1)\end{array}$ & $\begin{array}{l}0.303 \\
(12.8)\end{array}$ & $\begin{array}{l}0.230 \\
(9.7)\end{array}$ & $\begin{array}{l}0.201 \\
(8.5)\end{array}$ & 2.369 & 0.144 \\
\hline$r$ & & $\begin{array}{l}0.705 \\
(100)\end{array}$ & - & - & - & & \\
\hline $\mathrm{S}$ & $\mathrm{Y}, \mathrm{D}, \mathrm{G}$ & $\begin{array}{l}0.058 \\
(2.5)\end{array}$ & $\begin{array}{l}0.303 \\
(13.3)\end{array}$ & $\begin{array}{l}0.230 \\
(10.1)\end{array}$ & $\begin{array}{l}0.201 \\
(8.8)\end{array}$ & 2.283 & 0.058 \\
\hline$r$ & & $\begin{array}{l}0.553 \\
(100)\end{array}$ & - & - & - & & \\
\hline $\mathrm{D}$ & $\mathrm{Y}, \mathrm{S}, \mathrm{G}$ & $\begin{array}{l}0.152 \\
(6.4)\end{array}$ & $\begin{array}{l}0.303 \\
(12.7)\end{array}$ & $\begin{array}{l}0.230 \\
(9.7)\end{array}$ & $\begin{array}{l}0.201 \\
(8.5)\end{array}$ & 2.377 & 0.152 \\
\hline$r$ & & $\begin{array}{l}0.760 \\
(100)\end{array}$ & - & - & - & & \\
\hline G & $\mathrm{Y}, \mathrm{S}, \mathrm{D}$ & $\begin{array}{l}0.075 \\
(3.2)\end{array}$ & $\begin{array}{l}0.022 \\
(0.9)\end{array}$ & $\begin{array}{l}0.014 \\
(0.6)\end{array}$ & $\begin{array}{l}0.303 \\
(13.0)\end{array}$ & 2.335 & 0.110 \\
\hline$r$ & & $\begin{array}{l}0.523 \\
(67.3)\end{array}$ & $\begin{array}{l}0.404 \\
(19.8)\end{array}$ & $\begin{array}{l}0.339 \\
(12.6)\end{array}$ & - & & \\
\hline
\end{tabular}

evident around the shelf break $(\simeq 200 \mathrm{~m})$. This coincides to a great extent with the zonation reported in the northwest Mediterranean (Abelló et al. 1988) and in other areas of the North Atlantic (Lagardère 1973, 1977a; Haedrich et al. 1975, 1980; Markle et al. 1988; Olaso 1990; García-Castrillo and Olaso 1995). The distribution and abundance patterns of the various species on the coast of Galicia coincide with those described in earlier studies (González-Gurriarán 1987; González-Gurriarán and Olaso 1987; Freire et al. 1991, 1992; GonzálezGurriarán et al. 1993; Fariña et al. 1994; Fariña and Pereiro 1995) and with other studies done in the northeast Atlantic (Lagardère 1973, 1977a; Olaso 1990; García-Castrillo and Olaso 1995). Our results point to an increase in abundance and diversity of decapod crustaceans with depth. However, other studies report that on the middle and lower slope, these parameters decrease again (Haedrich et al. 1975, 1980), with the exception of the submarine canyons located on the slope where biomass and density undergo a substantial increase (Sardá et al. 1994a).

In addition to being associated with depth, the spatial structure of the shelf and upper slope crustacean assemblages is related to sediment granulometry that particularly affects benthic species, and to water masses and circulation patterns that affect benthopelagic species (Lagardère 1973, 1977a; Abelló et al. 1988; Basford et al. 1989; Macpherson 1991; Bianchi 1992a,b; Setubal 1992). In deep zones where physical factors are more stable, food availability plays an essential role in zonation (Lagardère 1977a,b; Cartes and Sardá 1993). In our study area, the faunal zonation may be attributable more to oceanographic and sediment changes than to biogeographic factors, since the area is relatively small and the faunal composition resembles other zones located to the north and even in the Mediterranean (La- 

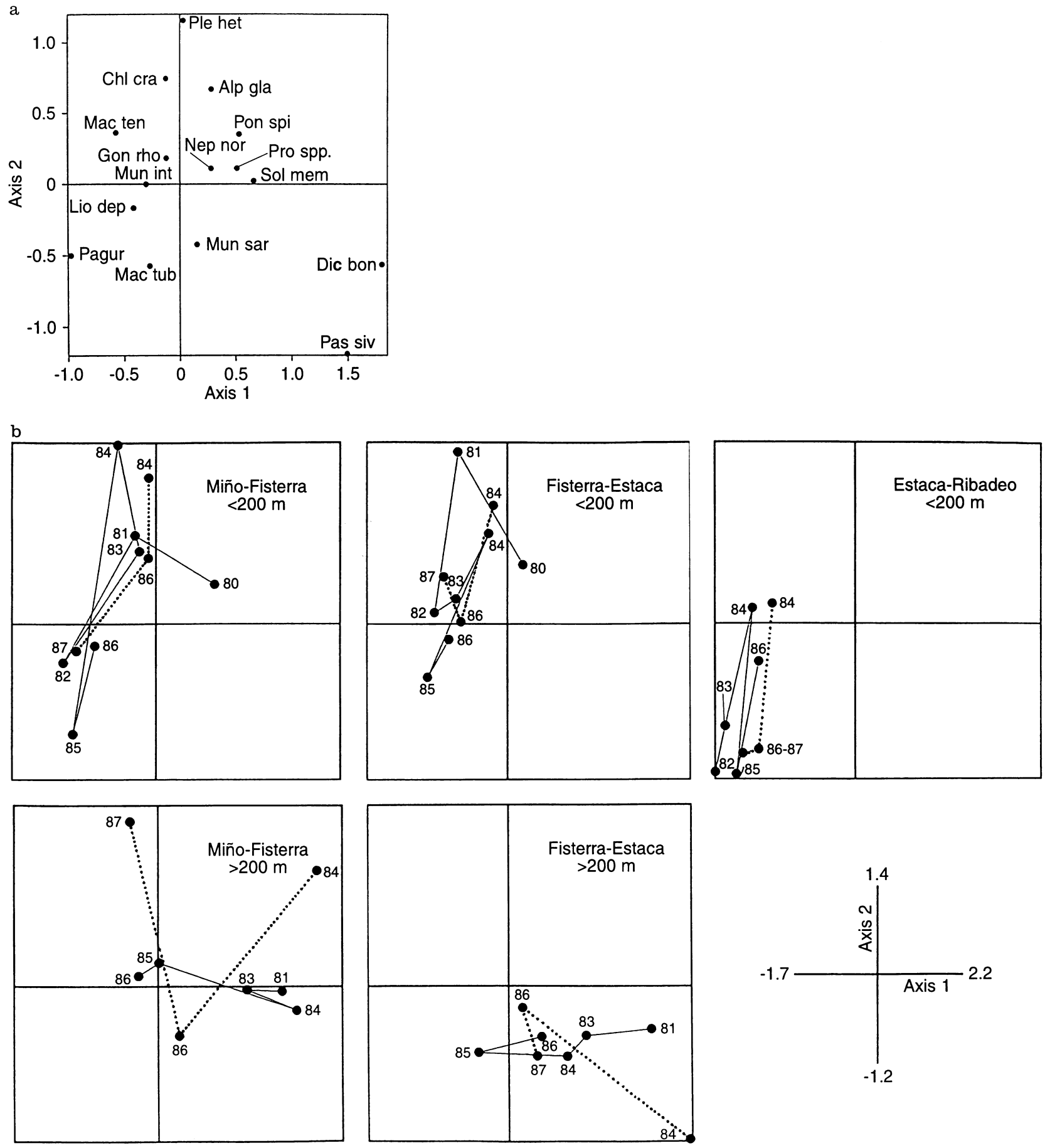

Fig. 8 Correspondence analysis of surveys carried out in autumn (1980 to 1986) and spring (1984, 1986 and 1987). a Scores of species of decapod crustaceans on Axes 1 and 2 (species codes as in Table 1); b centroids of tows for each survey, season (continuous line autumn, dotted line spring), geographic area, and depth stratum (for simplicity, temporal evolution on plane formed by Axes 1 and 2 of each area and stratum are presented on separate graphs)

gardère 1973; Abelló et al. 1988; Olaso 1990; Cartes 1993a). The faunal zonation observed in this study can be related to the spatial heterogeneity of the physical characteristics of the study area. The species that inhabit the south of the Galician continental margin are benthic, and in many cases exhibit burrowing behavior, depending on the existence of fine sediment (Lagardère
1973, 1977a), which is common in this area due to the outwelling from the Rías Baixas (López-Jamar et al. 1992). The zone directly to the north of Fisterra, where benthopelagic shrimps are abundant, is characterized by a convergence of water masses and upwelling processes with high productivity (Fraga 1981; McClain et al. 1986). Benthic crabs are typical of the area between 

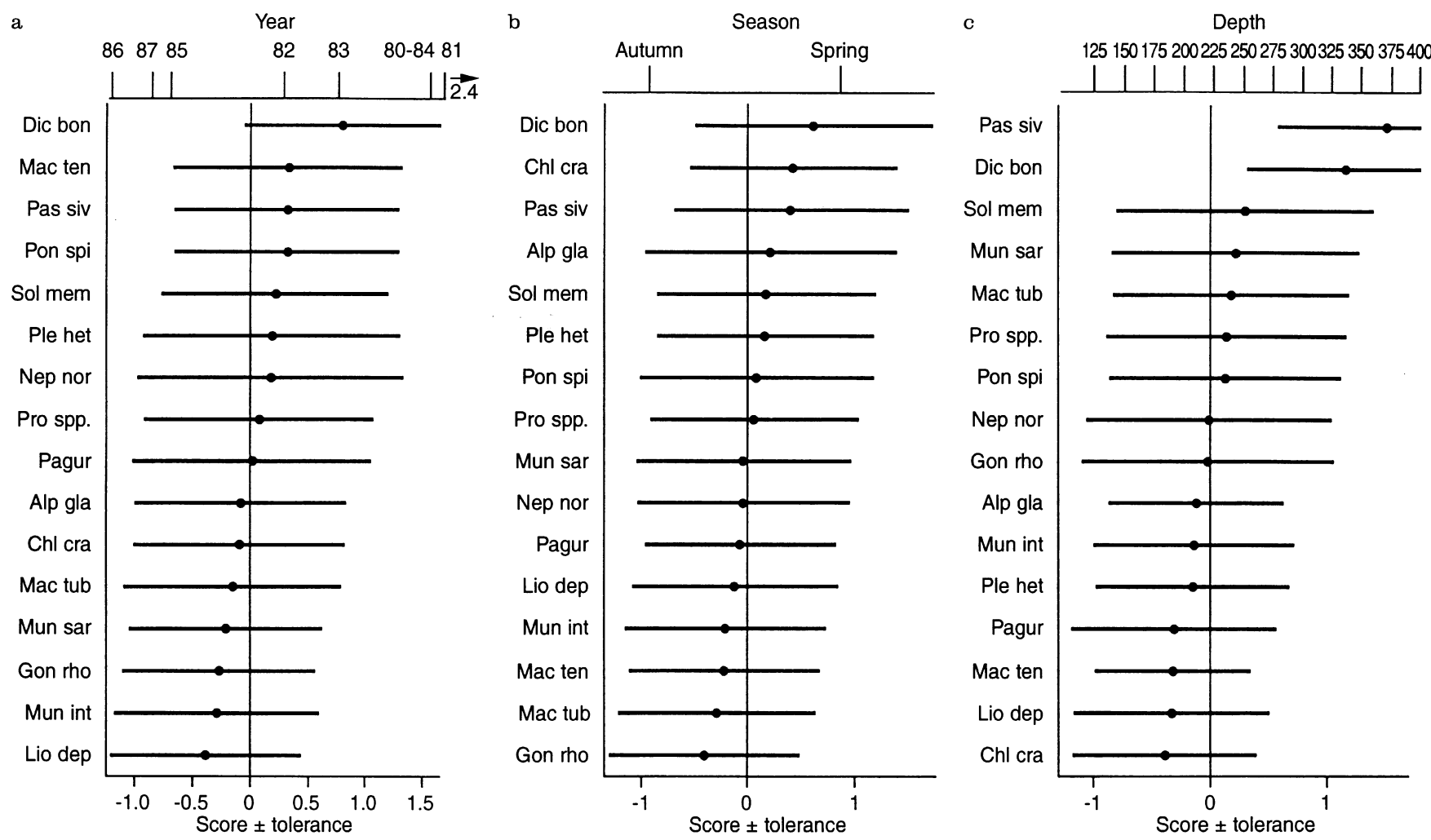

Fig. 9 Ordination of species of decapod crustaceans obtained from partial canonical correspondence analyses analyzing effect of year, season and depth on assemblage structure. Score \pm tolerance (root mean-square deviation) of each species and centroid of each survey (a) and season (b), and ordination of the bathymetric gradient (obtained by linear regression of depth in respect to score of the tow) (c) along the first axis are given (Species codes as in Table 1)

Fisterra and Estaca, although they have a broad spatial distribution. This area has a high level of infaunal biomass as a result of the upwelling processes, even though the sediment is coarser and the organic content lower than to the south of the shelf (López-Jamar and González 1987; López-Jamar et al. 1992).

Despite the fact that about half the species on the continental shelf and slope of Galicia have also been reported in the rías (between 5 and $50 \mathrm{~m}$ depth) (González-Gurriarán and Méndez 1985; González-Gurriarán and Olaso 1987), the community structure in the two zones is completely different, so that only Liocarcinus depurator and occasionally Polybius henslowii are dominant species common to both zones (GonzálezGurriarán 1982, 1986; Romero et al. 1982; Iglesias and González-Gurriarán 1984; González-Gurriarán and Olaso 1987; González-Gurriarán et al. 1991).

The spatial organization of megabenthic crustacean assemblages and of demersal fish assemblages shows very different patterns in our study area as well as in other zones. The spatial and temporal changes in the demersal fishes of the Galician coast are mainly associated with oceanographic phenomena displaying great seasonal and interannual variability (Fariña et al. 1997), whereas in decapods the more stable sediment and oceanographic conditions are of greater importance. In the case of fishes, which are more mobile and in many cases carry out ontogenetic migrations through the bathymetric gradient, faunal zonation and spatial structure of the assemblage is of little importance (Markle et al. 1988; Haedrich and Merrett 1990; Macpherson and Duarte 1991; Fariña et al. 1997). Migrations of decapod crustaceans are less important, although the benthopelagic species carry out seasonal and diel vertical movements along the bathymetric gradient (Lagardère 1977a,b; Cartes et al. 1993; Sardá et al. 1994b). On the other hand, some of the dominant species of demersal fishes on the Galician shelf make use of the rías either seasonally or during some life-history stages (Fariña et al. 1997), indicating the importance of mobility and migrations in assemblage structure. In crustaceans, as mentioned earlier, there is very little interchange between the assemblages in the rías and those on the shelf.

The abundance and diversity of fishes on the Galician continental margin decreased with depth, displaying opposite patterns to crustaceans (Fariña et al. 1997; and present paper); this agrees with the inverse relationship between fishes and invertebrates proposed by Haedrich et al. $(1975,1980)$. Similarly, in the Mediterranean, the dominant species of demersal fishes in the shelf are replaced by benthopelagic crustaceans on the upper slope (Sardá et al. 1994a). These distribution patterns may be caused in part by the trophic interactions between the 


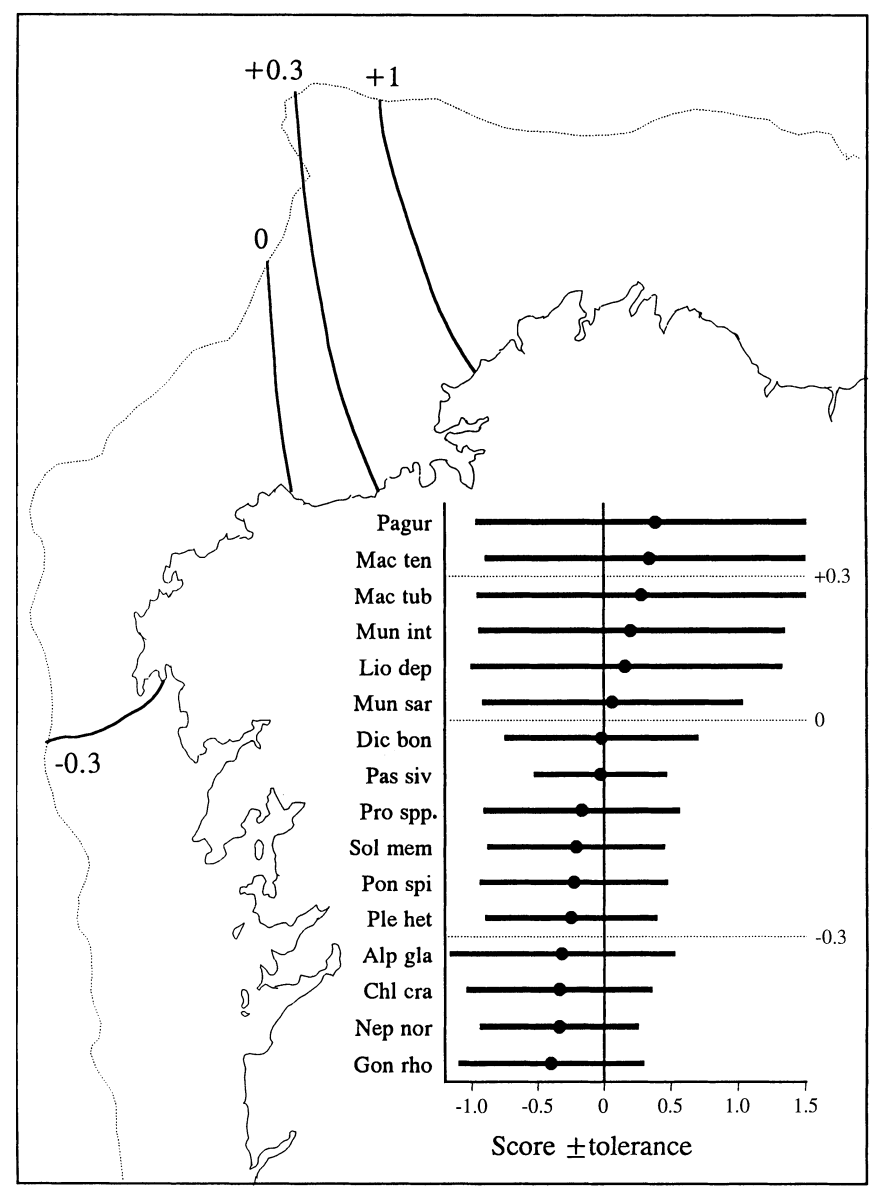

Fig. 10 Geographic distribution of scores of tows and species obtained from partial canonical correspondence analysis analyzing spatial structure of assemblage of decapod crustaceans (variables = latitude, longitude, latitude $\times$ longitude; covariates $=$ year, season and depth). Isolines of tow scores on first axis are shown (mapping based on regression: score $=b_{1}+b_{2} \times$ latitude $+b_{3} \times$ longitude $+b_{4} \times$ latitude $\times$ longitude), together with score \pm tolerance (root mean-square deviation) of each species (Species codes as in Table 1)

two groups. In fact the juvenile stages and small-sized species of demersal fishes, which prey mostly on invertebrates (Macpherson 1981; González et al. 1985; Olaso 1990; Olaso and Rodríguez-Marín 1995), are more abundant in shallow waters (Macpherson and Duarte 1991; Fariña et al. 1997).

Decapod crustaceans play an important ecological role within the megabenthic assemblages on the continental margins, owing to their abundance and trophic relationships. Species such as Nephrops norvegicus, Liocarcinus depurator, Macropipus tuberculatus, Solenocera membranacea or Paguridae prey on epibenthic and infaunal organisms (Thomas and Davidson 1962; Lagardère 1977a,b; Abelló and Cartes 1987; Froglia and Gramitto 1987; Abelló 1989; Baden et al. 1990; Freire 1996). Various benthopelagic shrimps such as Dichelopandalus bonnieri, Pasiphaea spp., Plesionika spp., and others prey on benthic, suprabenthic and mesopelagic organisms (Lagardère 1977a,b; Cartes 1991, 1993b,c). Polybius henslowii also has a diet composed of benthic organisms and pelagic fishes and cephalopods (E. Poza and E. González-Gurriarán, unpublished data). It has been suggested that megabenthic decapods have an important scavenging role, feeding particularly on fishes. On the other hand, several decapod species constitute a large part of the diet of demersal fishes that are dominant on the coasts of Galicia (Macpherson 1981; González et al. 1985; Olaso 1990; Olaso and RodríguezMarín 1995). These data along with the results of this study suggest that the dominant decapod species on the Galician continental margin constitute an intermediate trophic level, and are a key factor in energy flow to higher levels of the food web and, in the case of the benthopelagic species, in the process of benthopelagic coupling.

Acknowledgements We would like to thank all those involved in the demersal trawl surveys on the Galician coast carried out by the Instituto Español de Oceanografía between 1980 and 1987 for their valuable help. C.P. Teed assisted in the preparation of the English version of the manuscript.

\section{References}

Abelló P (1989) Feeding habits of Macropipus tuberculatus (Brachyura, Portunidae) off the Catalan coast (NW Mediterranean). Miscellània zool 13: 45-50

Abelló P, Cartes J (1987) Observaciones sobre la alimentación de Liocarcinus depurator (L.) (Brachyura: Portunidae) en el Mar Catalán. Investigación pesq 51(Supl 1): 413-419

Abelló P, Valladares FJ, Castellón A (1988) Analysis of the structure of decapod crustacean assemblages off the Catalan coast (North-West Mediterranean). Mar Biol 98: 39-49

Allen JA (1968) The surface swarming of Polybius henslowi [Brachyura: Portunidae]. J mar biol Ass UK 48: 107-111

Alonso-Allende JM (1980) Distribución de la cigala (Nephrops norvegicus) en las costas de Galicia. Investigación pesq 44: $347-$ 360

Alonso-Allende JM (1982) Abundancia de la cigala (Nephrops norvegicus) (Decapoda: Reptantia) en las costas de Galicia. Investigación pesq 46: 63-82

Baden SP, Pihl L, Rosenberg R (1990) Effects of oxygen depletion on the ecology, blood physiology and fishery of the Norway lobster Nephrops norvegicus. Mar Ecol Prog Ser 67: 141-155

Basford DJ, Eleftheriou A, Raffaelli D (1989) The epifauna of the northern North Sea $\left(56^{\circ}-61^{\circ} \mathrm{N}\right)$. J mar biol Ass UK 69: $387-$ 407

Bianchi G (1992a) Demersal assemblages of the continental shelf and upper slope of Angola. Mar Ecol Prog Ser 81: 101-120

Bianchi G (1992b) Study of the demersal assemblages of the continental shelf and upper slope off Congo and Gabon, based on the trawl surveys of the RV 'Dr Fridtjof Nansen'. Mar Ecol Prog Ser 85: 9-23

Blanton JO, Atkinson LP, Fernández de Castillejo F, Lavín A (1984) Coastal upwelling off the Rías Bajas, Galicia, Northwest Spain. I. Hydrographic studies. Rapp P-v Réun Cons perm int Explor Mer 183: 79-90

Borcard D, Legendre P, Dapreau P (1992) Partialling out the spatial component of ecological variation. Ecology 73: 1045-1055

Cartes JE (1991) Análisis de las comunidades y estructura trófica de los crustáceos decápodos batiales del Mar Catalán. Ph D thesis. Universidad Politécnica de Catalunya, Barcelona, Spain

Cartes JE (1993a) Deep-sea decapod fauna of the Western Mediterranean: bathymetric distribution and biogeographic aspects. Crustaceana 65: 29-40 
Cartes JE (1993b) Feeding habits of pasiphaeid shrimps close to the bottom of the Western Mediterranean slope. Mar Biol 117: $459-468$

Cartes JE (1993c) Diets of deep-water pandalid shrimps on the Western Mediterranean slope. Mar Ecol Prog Ser 96: 49-61

Cartes JE, Company JB, Maynou F (1994) Deep-water decapod crustacean communities in the Northwestern Mediterranean: influence of submarine canyons and season. Mar Biol 120: 221229

Cartes JE, Sardá F (1992) Abundance and diversity of decapod crustaceans in the deep-Catalan Sea (Western Mediterranean). J nat Hist 26: 1305-1323

Cartes JE, Sardá F (1993) Zonation of deep-sea decapod fauna in the Catalan Sea (Western Mediterranean). Mar Ecol Prog Ser 94: $27-34$

Cartes JE, Sardá F, Company JB, Lleonart J (1993) Day-night migrations by deep-sea decapod crustaceans in experimental samplings in the Western Mediterranean Sea. J exp mar Biol Ecol 171: 63-73

Fariña AC, Freire J, González-Gurriarán E (1994) Nephrops norvegicus in the Galician continental shelf (NW Spain): abundance and distribution. Fish Res 19: 333-347

Fariña AC, Freire J, González-Gurriarán E (1997) Demersal fish assemblages in the Galician continental shelf and upper slope (NW Spain): spatial structure and long-term changes. Estuar, cstl Shelf Sci (in press)

Fariña AC, Pereiro FJ (1995) Distribution and abundance of molluscs and decapod crustaceans in trawl samples from the Galician Shelf (NW Spain). ICES mar Sci Symp (Act Symp) 199: 189-199

Fernández A, Pereiro FX, Iglesias S, Porteiro C, Pallarés P (1978) La pesquería demersal gallega. Estrategias de pesca para su regulación racional en base a la merluza. Boln Inst esp Oceanogr 4: 67-109

Fraga F (1981) Upwelling off the Galician coast, Northwest Spain. In: Richards FA (ed) Coastal upwelling. American Geophysical Union, Washington DC, 176-182

Freire J (1996) Feeding ecology of Liocarcinus depurator (Decapoda: Portunidae) in the Ría de Arousa (Galicia, north-west Spain): effects of habitat, season, and life history. Mar Biol 126: 297-311

Freire J, González-Gurriarán E, Olaso I (1992) Spatial distribution of Munida intermedia and M. sarsi (Crustacea: Anomura) on the Galician continental shelf (NW Spain): application of geostatistical analysis. Estuar, cstl Shelf Sci 35: 637-648

Freire J, González-Gurriarán E, Olaso I, Fernández L (1991) Análisis geoestadístico de la distribución espacial de Plesionika heterocarpus y Solenocera membranacea (Crustacea: Decapoda) en la plataforma continental de Galicia (NW España). Boln Inst esp Oceanogr 7: 79-88

Froglia C, Gramitto ME (1987) Notes on growth and biology of Solenocera membranacea (Risso, 1816) in the Central Adriatic Sea (Decapoda: Solenoceridae). Investigación pesq 51(Supl 1): 189-199

García-Castrillo G, Olaso I (1995) Composition and structure of the invertebrate megabenthos on the shelf of the Cantabrian Sea. ICES mar Sci Symp (Act Symp) 199: 151-156

González R, Olaso I, Pereda P (1985) Contribución al conocimiento de la alimentación de la merluza (Merluccius merluccius L.) en la plataforma continental de Galicia y del Cantábrico. Boln Inst esp Oceanogr 2: 49-60

González-Gurriarán E (1982) Estudio de la comunidad de crustáceos decápodos (Brachyura) en la Ría de Arousa (Galicia NW España), y su relación con el cultivo de mejillón en batea. Boln Inst esp Oceanogr 7: 223-254

González-Gurriarán E (1986) Seasonal changes of benthic megafauna in the Ría de Muros e Noia (Galicia, North-West Spain). II. Decapod crustaceans (Brachyura). Mar Biol 92: 201-210

González-Gurriarán E (1987) El patexo Polybius henslowii Leach (Decapoda-Brachyura), en las costas de Galicia (NW de España): I. Distribución espacial y cambios temporales. Investigación pesq 51(Supl 1): 361-374
González-Gurriarán E, Fernández L, Freire J, Muiño R, Rodríguez Solórzano M (1991) Estructura de la comunidad megabentónica (crustáceos decápodos - Brachyura - y peces demersales) de la Ría de Ferrol (Galicia, NW España). Boln Inst esp Oceanogr 7: 89-99

González-Gurriarán E, Freire J, Fernández L (1993) Geostatistical analysis of spatial distribution of Liocarcinus depurator, Macropipus tuberculatus and Polybius henslowii (Crustacea: Brachyura) over the Galician continental shelf (NW Spain). Mar Biol 115: 453-461

González-Gurriarán E, Méndez M (1985) Crustáceos decápodos das coastas de Galicia. I. Brachyura. Cuad Área Ciencias biol, Semin Estud Galegos 2: 1-242

González-Gurriarán E, Olaso I (1987) Cambios espaciales y temporales de los crustáceos decápodo de la plataforma continental de Galicia (NW de España). Investigación pesq 51(Supl 1): 323 341

Haedrich RL, Merrett NR (1990) Little evidence of faunal zonation or communities in deep sea demersal fish fauna. Prog Oceanogr 24: 239-250

Haedrich RL, Rowe GT, Polloni PT (1975) Zonation and faunal composition of epibenthic populations on the continental slope south of New England. J mar Res 33: 191-212

Haedrich RL, Rowe GT, Polloni PT (1980) The megabenthic fauna in the deep sea south of New England, USA. Mar Biol 57: 165179

Iglesias J, González-Gurriarán E (1984) Primeros datos sobre la megafauna bentónica de la ría de Pontevedra: peces demersales y crustáceos decápodos (Brachyura). Cuad Area Ciencias mar, Semin Estud Galegos 1: 303-319

Lagardère JP (1973) Distribution des décapodes dans le sud du Golfe de Gascogne. Revue Trav Inst (scient tech) Pêch marit 37: $77-95$

Lagardère JP (1977a) Recherches sur la distribution verticale et sur l'alimentation des crustaces decapodes bentiques de la pente continentale du Golfe de Gascogne. Analyse des groupements carcinologiques. Bull Cent Étud Rech scient Biarritz 11: 367-440

Lagardère JP (1977b) Recherches sur le r'egime alimentaire et le comportment prédateur des decapodes benthiques de la pente continentale de l'Atlantique Nord riental (Golfe de Gascogne et Maroc). In: Keegan BF, Ceidigh PO, Boaden PSJ (eds) Biology of benthic organisms. Pergamon Press, New York, pp 397-408

López -Jamar E, Cal RM, González G, Hanson RB, Rey J, Santiago G, Tenore KR (1992) Upwelling and outwelling effects on the benthic regime of the continental shelf off Galicia, NW Spain. J mar Res 50: 465-488

López-Jamar E, González G (1987) Infaunal macrobenthos of the Galician continental shelf off La Coruña Bay, Northwest Spain. Biol Oceanogr 4: 165-192

Macpherson E (1981) Resource partitioning in a Mediterranean demersal fish community. Mar Ecol Prog Ser 4: 183-193

Macpherson E (1991) Biogeography and community structure of the decapod crustacean fauna off Namibia (southeast Atlantic). J Crustacean Biol 11: 401-415

Macpherson E, Duarte CM (1991) Bathymetric trends in demersal fish size: is there a general relationship?. Mar Ecol Prog Ser 71: 103-112

Markle DF, Dadswell MJ, Halliday RG (1988) Demersal fish and decapod crustacean fauna of the upper continental slope off Nova Scotia from LaHavre to St. Pierre Banks. Can J Zool 66: 1952-1960

McClain CR, Chao SY, Atkinson LP, Blanton JO, Fernández de Castillejo F (1986) Wind-driven upwelling in the vicinity of Cape Finisterre, Spain. J geophys Res 91: 8470-8486

Olaso I (1990) Distribución y abundancia del megabentos invertebrado en fondos de la plataforma cantábrica. Publnes esp Inst españ Oceanogr, Madrid 5: 1-128

Olaso I, Rodríguez-Marín E (1995) Decapod crustaceans in the diets of demersal fish in the Cantabrian Sea. ICES mar Sci Symp (Act Symp) 199: 209-221

Penas E (1986) Modelo preliminar del ecosistema de la plataforma continental de Galicia. Boln Inst esp Oceanogr 3: 43-56 
Romero P, González-Gurriarán E, Penas E (1982) Influence of mussel rafts on spatial and seasonal abundance of crabs in the Ría de Arousa, North-West Spain. Mar Biol 72: 201-210

Sánchez F, Pereiro FJ, Rodríguez-Marín E (1991) Abundance and distribution of the main commercial fish on the Northern coast of Spain (ICES divisions VIIIc and IXa) from bottom trawl surveys. Int Counc Explor Sea Comm Meet (Demersal Fish Comm) 1991/G: 53: 1-30

Sardá F, Cartes JE, Company JB (1994a) Spatio-temporal variations in megabenthos abundance in three different habitats of the Catalan deep-sea (Western Mediterranean). Mar Biol 120: 211-219

Sardá F, Cartes JE, Norbis W (1994b) Spatio-temporal structure of the deep-water shrimp Aristeus antennatus (Decapoda: Aristeidae) population in the western Mediterranean. Fish Bull US 92: 599-607

Setubal AM (1992) Structure and dynamics of benthic megafauna on the continental shelf offshore of Ubatuba, southeastern Brazil. Mar Ecol Prog Ser 86: 63-76

Tenore KR, Cal RM, Hanson RB, López-Jamar E, Santiago G, Tietjen JH (1984) Coastal upwelling off the Rías Bajas, Galicia, Northwest Spain. II. Benthic studies. Rapp P-v Réun Cons perm int Explor Mer 183: 91-100
Ter Braak CJF (1986) Canonical correspondence analysis: a new eigenvector technique for multivariate direct gradient analysis. Ecology 67: 1167-1179

Ter Braak CJF (1987) CANOCO - A FORTRAN program for canonical community ordination by [partial] [detrended] [canonical] correspondence analysis, principal component analysis and redundancy analysis. TNO Institute of Applied Computer Science, Wageningen, The Netherlands

Ter Braak CJF (1988) Partial canonical correspondence analysis. In: Bock $\mathrm{HH}$ (ed) Classification and related methods of data analysis. Elsevier, North Holland, pp 551-558

Thomas HJ, Davidson C (1962) The food of the Norway lobster. Mar Res 3: 1-15

Trujillo V, Meixide M, Porteiro C, Pérez N, Pereiro FJ (1993) Cambios de malla y esfuerzo en las pesquerías multiespecíficas en aguas atlánticas de la Península Ibérica. Boln Inst esp Oceanogr 9: 23-40

Varela M (1992) Upwelling and phytoplankton ecology in Galician (NW Spain) rías and shelf waters. Boln Inst esp Oceanogr 8: $57-74$

Wenner EL, Boesch DF (1979) Distribution patterns of epibenthic decapod Crustacea along the shelf-slope coenocline, Middle Atlantic Bight, USA. Bull biol Soc Wash 3: 106-133 